\title{
Hydrosilylation of Olefins Catalyzed by Iron Complexes Bearing Ketimine-Type Iminobipyridine Ligands
}

\author{
Yuki Toya, Kazumasa Hayasaka, Hiroshi Nakazawa
}

\begin{tabular}{|c|l|}
\hline Citation & Organometallics, 36(9); 1727-1735 \\
\hline Issue Date & $2017-04-20$ \\
\hline Type & Journal Article \\
\hline Textversion & author \\
\hline Rights & $\begin{array}{l}\text { This document is the Accepted Manuscript version of a Published Work that appeared in } \\
\text { final form in Organometallics, copyright } @ \text { American Chemical Society after peer review } \\
\text { and technical editing by the publisher. To access the final edited and published work see } \\
\text { https://doi.org/10.1021/acs.organomet.7b00087. }\end{array}$ \\
\hline DOI & \begin{tabular}{l}
$10.1021 /$ acs.organomet.7b00087 \\
\hline
\end{tabular} \\
\hline
\end{tabular}

\author{
Self-Archiving by Author(s) \\ Placed on: Osaka City University
}

Toya, Y., Hayasaka, K., \& Nakazawa, H. (2017). Hydrosilylation of Olefins Catalyzed by Iron Complexes Bearing Ketimine-Type Iminobipyridine Ligands. Organometallics, 36, 1727-1735. https://doi.org/10.1021/acs.organomet.7b00087 


\title{
Hydrosilylation of Olefins Catalyzed by Iron Complexes Bearing Ketimine-type Iminobipyridine Ligands
}

\author{
Yuki Toya, Kazumasa Hayasaka, and Hiroshi Nakazawa* \\ Department of Chemistry, Graduate School of Science, Osaka City University, Sumiyoshi-ku, Osaka 558-8585. \\ Supporting Information Placeholder
}

\begin{abstract}
A series of NNN-pincer iron complexes bearing ketimine-type iminobipyridene (BPI) ligands were prepared. These iron complexes were effective catalysts for the hydrosilylation of olefins using primary, secondary, and tertiary silanes. The effect of the substituents on the imino carbon on the catalytic activity was examined, and it was found that the appropriate combination of the imino carbon and imino nitrogen substituents led to complexes with quite high catalytic activity: the turnover number achieved was up to 42000. These iron catalytic systems provide a low-cost and promising alternative to currently employed precious metal systems for the hydrosilylation of olefins.
\end{abstract}

\section{INTRODUCTION}

Catalytic hydrosilylation of olefins is one of the most straightforward and atom-economic methods to synthesize organosilanes, which are versatile and indispensable compounds. ${ }^{1}$ Platinum catalysts such as Karstedt's and Speier's catalysts are known to be very effective for olefin hydrosilylation. $^{2}$ However, platinum is a precious metal. Therefore, the development of base-metal catalysts for the hydrosilylation reaction of olefins is one of the most important and urgent topics of research.

As iron is a typical base metal; many iron complexes have been investigated for the hydrosilylation of olefins, and several effective iron complexes have been reported. It is generally important to select an appropriate ligand that suitably coordinates to the transition metal in order to render a highly active homogeneous catalyst. ${ }^{3}$ To date, published work shows that $\mathrm{Fe}^{4-11}$ and $\mathrm{Co}^{12}$ complexes, bearing pincer-type ligands, are effective hydrosilylation catalysts.

Chirik and co-workers showed that the NNN pincer-type ligand 2,6-diiminopyridine (PDI) was a good ligand for the iron-catalyzed hyrosilylation of olefins. The nitrogen complex (PDI)Fe( $\left.\mathrm{N}_{2}\right)_{2}$ exhibited higher hydrosilylation catalytic activity than any iron catalyst reported so far. ${ }^{4}$ However, it was found to be very unstable towards air and moisture. Chirik's group reported that the corresponding dialkyl complex, (PDI)FeR $\mathrm{R}_{2}$, was more robust and maintained high catalytic activity. However, high temperatures were required to activate this catalyst. Iron complexes bearing NNN and PNN pincertype ligands have been reported to be good hydrosilylation catalysts (Figure 1). ${ }^{4-9}$ Our group and Chirik's group reported that iron complexes bearing the NNN pincer-type ligand terpyridine, (terpy)FeX $\mathrm{F}_{2}$, effectively catalyzed the hydrosilylation of olefins. ${ }^{4 c, 5}$ It should be noted that the bulkiness of PDI and terpy substituents situated near the iron active site greatly affected the catalytic activity: the bulkiness of the substituents on the imino nitrogens of PDI and that on 5,6,5', and 6' posi- tions of terpy played a crucial role in the catalytic activity.

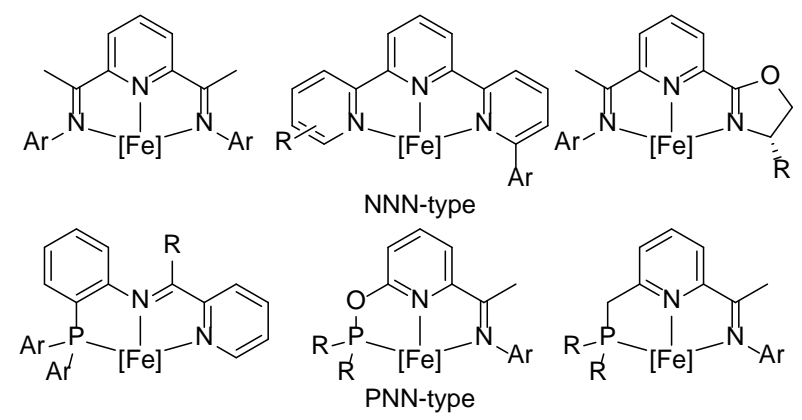

Figure 1. Iron complexes bearing NNN and PNN pincer-type ligands.

Other notable examples of NNN pincer-type iron complexes showing catalytic activity for olefin hydrosilylation have been reported by the research groups of $\mathrm{Lu}^{6}$ and Thomas. ${ }^{7}$ Moreover, Walter and Huang reported that iron complexes bearing PNN pincer-type ligands were also effective catalysts for the hydrosilylation of olefins. ${ }^{8}$ These iron complexes exhibited functional group tolerance towards reactive functionalities, such as ketones, esters, and amides.

We recently reported that the NNN pincer-type ligand 6imino-2,2'-bipyridine (BPI) was an appropriate ligand for Fe. The iron complexes (BPI) $\mathrm{FeBr}_{2}$ exhibited high catalytic activity for the hydrosilylation of olefins. ${ }^{10} \mathrm{NaBHEt}_{3}$ was required as a co-catalyst in this system to activate the iron complex. In these iminobipyridine iron complexes, the three substituents, R' (the substituent at the 6' position of the bipyridine unit), $\mathrm{R}$ (the substituent on the imino carbon), and Ar (the substituent on the imino nitrogen), are expected to affect the catalytic activity. Complexes with $\mathrm{R}=\mathrm{H}$ and $\mathrm{R}=$ hydrocarbon are denoted as aldimine- and ketimine-type iminobipyridine complexes, respectively (Figure 2). In a previous study, ${ }^{10}$ we ex- 
amined the effect of the substituents ( $\mathrm{R}^{\prime}$ and $\mathrm{Ar}$ ) on the aldimine-type (BPI)FeBr${ }_{2}$ on the catalytic activity; we found that an appropriate balance between substituents was important in designing better catalysts. A high turnover number (TON) of 12038 was reported for the hydrosilylation of 1octene with diphenylsilane $\left(\mathrm{Ph}_{2} \mathrm{SiH}_{2}\right)$. We surmised that the steric and/or electronic balance between the two substituents, the one on the imino carbon and the one on the imino nitrogen, was responsible for the catalytic activity. In this paper, we report the synthesis of iron complexes bearing ketimine-type iminobipyridine ligands, and examine their catalytic activity on the hydrosilylation of olefins.

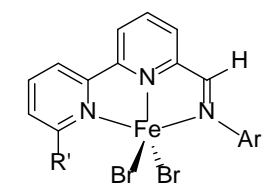

aldimine type iminobipyridine $\left({ }^{\mathrm{R}} \mathrm{BPI}^{\mathrm{Ar}, \mathrm{H}}\right) \mathrm{FeBr} 2$

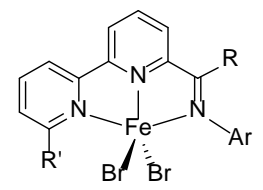

ketimine type iminobipyridine

$$
\left({ }^{\mathrm{R}} \mathrm{BPI}^{\mathrm{Ar}, \mathrm{R}}\right) \mathrm{FeBr} 2
$$

Figure 2. Iron complexes bearing aldimine- and ketimine-type iminobipyridines.

\section{RESULTS AND DISCUSSION}

Preparation of Ketimine-type Iminobipyridine Derivatives and Their Iron Complexes. The reaction sequences for the preparation of the iron complexes bearing an iminobipyridine derivative and two $\mathrm{Br}$ atoms are shown in Scheme 1. In this paper, the $\left({ }^{\mathrm{H}} \mathrm{BPI}^{\mathrm{Ar}, \mathrm{R}}\right) \mathrm{FeBr}_{2}\left(\mathrm{Ar}=\mathrm{Mes}\left[2,4,6-\mathrm{Me}_{3} \mathrm{C}_{6} \mathrm{H}_{2}\right.\right.$ ], Dipp [2,6- ${ }^{i} \mathrm{Pr}_{2} \mathrm{C}_{6} \mathrm{H}_{3}$ ], $\mathrm{R}=\mathrm{Me},{ }^{t} \mathrm{Bu}, \mathrm{CF}_{3}$ ) convention is used to describe the iron complexes, where $\mathrm{H}, \mathrm{Ar}$, and $\mathrm{R}$ stand for a substituent at the 6 -position of the bipyridine unit, that on the imino nitrogen, and that on the imino carbon, respectively. 1[2,2'-Bipyridine]-6-yl-ethanone derivatives 2 and $\mathbf{3}$ were obtained by treating 6-bromo-2,2'-bipyridine (1) with ${ }^{n} \mathrm{BuLi}$, followed by the addition of the corresponding $\mathrm{N}, \mathrm{N}$ dimethylacetamide derivatives $\left(\mathrm{Me}_{2} \mathrm{NC}(\mathrm{O}) \mathrm{R}: \mathrm{R}=\mathrm{Me}, \mathrm{CF}_{3}\right)$ (Scheme 1, a). 2,2-Dimethyl-1-[2,2'-bipyridine]-6-yl-1propanone (4) was prepared by methylation of 2 (Scheme 1, b). Next, the iminobipyridine derivatives 5-9 were obtained by the condensation between $\mathbf{2}, \mathbf{3}$, or $\mathbf{4}$ and the corresponding amines (Scheme 1, c). As the iminobipyridine derivative $\mathbf{6}$ was found to be unstable, it was used without isolation. Finally, these iminobipyridine derivatives were treated with iron(II) bromide $\left(\mathrm{FeBr}_{2}\right)$ in THF to give the corresponding iron complexes $\left(\left({ }^{\mathrm{H}} \mathrm{BPI}^{\mathrm{Ar}, \mathrm{R}}\right) \mathrm{FeBr}_{2}\right)$ (Scheme 1, d). The iron complexes and their precursors shown in Scheme 1 were characterized by NMR and/or elemental analysis.

Hydrosilylation of 1-Octene with Primary, Secondary, and Tertiary Hydrosilanes Catalyzed by $\left({ }^{\mathrm{H}} \mathrm{BPI}^{\mathrm{Ar}, \mathrm{R}}\right) \mathrm{FeBr}_{2}$. $\left({ }^{\mathrm{H}} \mathrm{BPI}^{\mathrm{Ar}, \mathrm{R}}\right) \mathrm{FeBr}_{2}$ (0.01 mol\% based on the concentration of the hydrosilane added later) was placed in a Schlenk tube. Then, the air in the tube was replaced with nitrogen, and silane and 1-octene (1:2 molar ratio) were added. Finally, $\mathrm{NaBHEt}_{3}(0.2$ mol\%) was added to the suspension with stirring at room temperature, and a homogeneous solution was obtained within a few minutes. This process was exothermic. The solution was stirred without any temperature control for $24 \mathrm{~h}$, and the reaction mixture was subsequently exposed to air. The resulting solution was analyzed by HPLC to determine the yields of the hydrosilylated product(s).

Scheme 1. Synthetic routes of iron complexes with ketimine-type iminobipyridine ligand ${ }^{\mathrm{a}}$

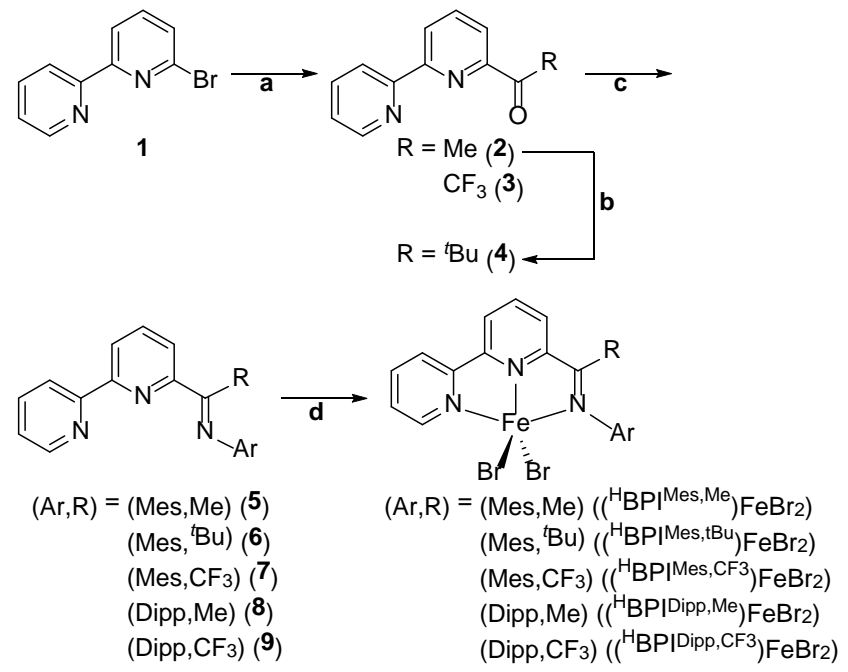

aConditions: (a) $n$-BuLi, $\mathrm{Me}_{2} \mathrm{NC}(\mathrm{O}) \mathrm{R}$ ( $\left.\mathrm{R}=\mathrm{Me}, \mathrm{CF}_{3}\right)$, in THF/hexane/ether, at $-78{ }^{\circ} \mathrm{C}$ (54-89\% yield); (b) $\mathrm{NaH}$, MeI, in THF, at $0{ }^{\circ} \mathrm{C}$ (79\% yield); (c) $\mathrm{ArNH}_{2}\left(\mathrm{Ar}=\mathrm{Mes}\right.$, Dipp), $\mathrm{H}^{+}$cat. (5, 8: formic acid, 6, 7, 9: $p$-toluenesulfonic acid monohydrate), in $\mathrm{MeOH}(\mathbf{5}, \mathbf{8})$ or toluene $(\mathbf{6}, \mathbf{7}, \mathbf{9})$, at reflux temperature $(43-88 \%$ yield); (d) anhydrous $\mathrm{FeBr}_{2}$, in THF, at room temperature (56$99 \%$ yield).

In order to compare the catalytic activity of our iminobipyridine iron complexes with that of Karstedt's catalyst, we also examined the hydrosilylation reaction catalyzed by Karstedt's catalyst under the same reaction conditions. The results are summarized in Table 1 . In all cases, selective antiMarkovnikov addition occurred and only 1-octyl-substituted silanes were formed; 2-octyl-substituented silanes or any other isomers were not detected.

TON (turnover number) was used to evaluate the catalytic activity. Some of the iron complexes were active enough to produce not only the monoalkylated silane but also the dialkylated silane. For example, when $\left({ }^{\mathrm{H}} \mathrm{BPI}^{\mathrm{Mes}, \mathrm{Me}}\right) \mathrm{FeBr}_{2}$ was used (Table 1, entry 2), the iron catalyst first converted $\mathrm{PhSiH}_{3}$ to $\mathrm{Ph}$ (octyl) $\mathrm{SiH}_{2}$ and this monoalkylated product reacted with further 1-octene, under the catalytic conditions, to give the dialkylated product $\mathrm{Ph}$ (octyl) $)_{2} \mathrm{SiH}$; the final yields were $56 \%$ and $26 \%$ for mono- and dialkylated products, respectively. The TON of this reaction was 5610 for $\mathrm{Ph}$ (octyl) $\mathrm{SiH}_{2}$ and 2640 for $\mathrm{Ph}(\text { octyl })_{2} \mathrm{SiH}$. In order to produce $\mathrm{Ph}(\text { octyl })_{2} \mathrm{SiH}$, hydrosilylation reaction occurs twice. Therefore, the overall hydrosilylation catalytic activity for $\left({ }^{\mathrm{H}} \mathrm{BPI}^{\mathrm{Mes}, \mathrm{Me}}\right) \mathrm{FeBr}_{2}$ is estimated to be 10890 (= $5610+2 \times 2640)$, which is denoted as "total TON" in this paper.

When $\left({ }^{\mathrm{H}} \mathrm{BPI}^{\mathrm{Mes}, \mathrm{R}}\right) \mathrm{FeBr}_{2}$ was used as hydrosilylation catalyst with the primary silane $\mathrm{PhSiH}_{3}$, the following features were 
Table 1. Hydrosilylation of 1-octene catalyzed by (BPI)FeBr2 and Karstedt's catalyst. ${ }^{a}$

\begin{tabular}{|c|c|c|c|c|c|c|}
\hline silane & + 2 eq 1-octene $\stackrel{\mathrm{Fe}}{\mathrm{Na}}$ & $\begin{array}{l}\text { plex cat. } \\
\text { it cat. } \\
24 \mathrm{~h}\end{array}$ & hydrosilylated & duct & & \\
\hline entry & Fe complex & $\mathrm{mol}^{\mathrm{b}}$ & silane & products (yield, TON) ${ }^{\mathrm{c}}$ & & total $\mathrm{TON}^{\mathrm{d}}$ \\
\hline 1 & $\left({ }^{\mathrm{H}} \mathrm{BPI}^{\mathrm{Mes}, \mathrm{H}}\right) \mathrm{FeBr}_{2}$ & 0.01 & $\mathrm{PhSiH}_{3}$ & $\mathrm{Ph}$ (octyl) $\mathrm{SiH}_{2}(21 \%, 2140)$ & $\mathrm{Ph}(\text { octyl })_{2} \mathrm{SiH}(1 \%, 80)$ & 2300 \\
\hline 2 & $\left({ }^{\mathrm{H}} \mathrm{BPI}^{\mathrm{Mes}, \mathrm{Me}}\right) \mathrm{FeBr}_{2}$ & & & $\mathrm{Ph}\left(\right.$ octyl) $\mathrm{SiH}_{2}(56 \%, 5610)$ & $\mathrm{Ph}(\text { octyl })_{2} \mathrm{SiH}(26 \%, 2640)$ & 10890 \\
\hline 3 & $\left({ }^{\mathrm{H}} \mathrm{BPI}^{\mathrm{Mes}, \mathrm{Bu}}\right) \mathrm{FeBr}_{2}$ & & & $\mathrm{Ph}$ (octyl) $\mathrm{SiH}_{2}(15 \%, 1480)$ & $\mathrm{Ph}(\text { octyl })_{2} \mathrm{SiH}(1 \%, 80)$ & 1640 \\
\hline 4 & $\left({ }^{\mathrm{H}} \mathrm{BPI}^{\mathrm{Mes}, \mathrm{CF} 3}\right) \mathrm{FeBr}_{2}$ & & & $\mathrm{Ph}$ (octyl) $\mathrm{SiH}_{2}(67 \%, 6660)$ & $\mathrm{Ph}(\text { octyl })_{2} \mathrm{SiH}(29 \%, 2850)$ & 12360 \\
\hline 5 & $\left({ }^{\mathrm{H}} \mathrm{BPI}^{\mathrm{Dipp}, \mathrm{H}}\right) \mathrm{FeBr}_{2}$ & & & $\mathrm{Ph}\left(\right.$ octyl) $\mathrm{SiH}_{2}(65 \%, 6460)$ & $\mathrm{Ph}$ (octyl) ${ }_{2} \mathrm{SiH}(31 \%, 3110)$ & 12680 \\
\hline 6 & $\left({ }^{\mathrm{H}} \mathrm{BPI}^{\mathrm{Dipp}, \mathrm{Me}}\right) \mathrm{FeBr}_{2}$ & & & $\mathrm{Ph}$ (octyl)SiH $\mathrm{Si}_{2}(60 \%, 5950)$ & $\mathrm{Ph}(\text { octyl })_{2} \mathrm{SiH}(8 \%, 750)$ & 7450 \\
\hline 7 & $\left({ }^{\mathrm{H}} \mathrm{BPI}{ }^{\text {Dipp,CF3 }}\right) \mathrm{FeBr}_{2}$ & & & $\mathrm{Ph}$ (octyl) $\mathrm{SiH}_{2}(63 \%, 6330)$ & $\mathrm{Ph}(\text { octyl })_{2} \mathrm{SiH}(7 \%, 680)$ & 7690 \\
\hline 8 & Karstedt's catalyst & & & $\mathrm{Ph}$ (octyl) $\mathrm{SiH}_{2}(3 \%, 260)$ & $\mathrm{Ph}(\text { octyl })_{2} \mathrm{SiH}(0 \%, 0)$ & 260 \\
\hline 9 & $\left({ }^{\mathrm{H} P I}{ }^{\mathrm{Mes}}, \mathrm{H}\right) \mathrm{FeBr}_{2}$ & 0.01 & $\mathrm{Ph}_{2} \mathrm{SiH}_{2}$ & $\mathrm{Ph}_{2}$ (octyl)SiH $(65 \%, 6480)$ & $\mathrm{Ph}_{2}(\text { octyl })_{2} \mathrm{Si}(0 \%, 0)$ & 6480 \\
\hline 10 & $\left({ }^{\mathrm{H}} \mathrm{BPI}^{\mathrm{Mes}, \mathrm{Me}}\right) \mathrm{FeBr}_{2}$ & & & $\mathrm{Ph}_{2}$ (octyl)SiH (31\%, 3120) & $\mathrm{Ph}_{2}$ (octyl) $)_{2} \mathrm{Si}(65 \%, 6460)$ & 16040 \\
\hline 11 & $\left({ }^{\mathrm{H}} \mathrm{BPI}^{\mathrm{Mes}, \mathrm{BBu}}\right) \mathrm{FeBr}_{2}$ & & & $\mathrm{Ph}_{2}$ (octyl)SiH $(42 \%, 4190)$ & $\mathrm{Ph}_{2}(\text { octyl })_{2} \mathrm{Si}(0 \%, 0)$ & 4190 \\
\hline 12 & $\left({ }^{\mathrm{H}} \mathrm{BPI}^{\mathrm{Mes}, \mathrm{CF} 3}\right) \mathrm{FeBr}_{2}$ & & & $\mathrm{Ph}_{2}$ (octyl)SiH (54\%, 5370) & $\mathrm{Ph}_{2}(\text { octyl })_{2} \mathrm{Si}(45 \%, 4490)$ & 14350 \\
\hline 13 & $\left({ }^{\mathrm{H}} \mathrm{BPI}^{\mathrm{Dipp}, \mathrm{H}}\right) \mathrm{FeBr}_{2}$ & & & $\mathrm{Ph}_{2}$ (octyl)SiH (94\%, 9380) & $\mathrm{Ph}_{2}$ (octyl) $)_{2} \mathrm{Si}(1 \%, 70)$ & 9520 \\
\hline 14 & $\left({ }^{\mathrm{H}} \mathrm{BPI}^{\mathrm{Dipp}, \mathrm{Me}}\right) \mathrm{FeBr}_{2}$ & & & $\mathrm{Ph}_{2}$ (octyl)SiH $(71 \%, 7100)$ & $\mathrm{Ph}_{2}$ (octyl) $)_{2} \mathrm{Si}(7 \%, 710)$ & 8520 \\
\hline 15 & $\left({ }^{\mathrm{H}} \mathrm{BPI}^{\mathrm{Dipp}, \mathrm{CF} 3}\right) \mathrm{FeBr}_{2}$ & & & $\mathrm{Ph}_{2}$ (octyl)SiH $(75 \%, 7530)$ & $\mathrm{Ph}_{2}$ (octyl) $)_{2} \mathrm{Si}(1 \%, 110)$ & 7750 \\
\hline 16 & Karstedt's catalyst & & & $\mathrm{Ph}_{2}$ (octyl)SiH (92\%, 9210) & $\mathrm{Ph}_{2}$ (octyl) $)_{2} \mathrm{Si}(0 \%, 0)$ & 9210 \\
\hline 17 & $\left({ }^{\mathrm{H}} \mathrm{BPI}^{\mathrm{Mes}, \mathrm{H}}\right) \mathrm{FeBr}_{2}$ & 0.1 & $\mathrm{Ph}_{2} \mathrm{MeSiH}$ & $\mathrm{Ph}_{2} \mathrm{Me}($ octyl)Si $(74 \%, 741)$ & & 741 \\
\hline 18 & $\left({ }^{\mathrm{H}} \mathrm{BPI}^{\mathrm{Mes}, \mathrm{Me}}\right) \mathrm{FeBr}_{2}$ & & & $\mathrm{Ph}_{2} \mathrm{Me}($ octyl)Si $(80 \%, 795)$ & & 795 \\
\hline 19 & $\left({ }^{\mathrm{H}} \mathrm{BPI}^{\mathrm{Mes}, \mathrm{tBu}}\right) \mathrm{FeBr}_{2}$ & & & $\mathrm{Ph}_{2} \mathrm{Me}($ octyl)Si $(13 \%, 132)$ & & 132 \\
\hline 20 & $\left({ }^{\mathrm{H}} \mathrm{BPI}^{\mathrm{Mes}, \mathrm{CF} 3}\right) \mathrm{FeBr}_{2}$ & & & $\mathrm{Ph}_{2} \mathrm{Me}($ octyl)Si $(65 \%, 645)$ & & 645 \\
\hline 21 & $\left({ }^{\mathrm{H}} \mathrm{BPI}^{\mathrm{Dipp}, \mathrm{H}}\right) \mathrm{FeBr}_{2}$ & & & $\mathrm{Ph}_{2} \mathrm{Me}($ octyl)Si $(49 \%, 494)$ & & 494 \\
\hline 22 & $\left({ }^{\mathrm{H}} \mathrm{BPI}^{\mathrm{Dipp}, \mathrm{Me}}\right) \mathrm{FeBr}_{2}$ & & & $\mathrm{Ph}_{2} \mathrm{Me}($ octyl)Si $(62 \%, 621)$ & & 621 \\
\hline 23 & $\left({ }^{\mathrm{H}} \mathrm{BPI}^{\mathrm{Dipp}, \mathrm{CF} 3}\right) \mathrm{FeBr}_{2}$ & & & $\mathrm{Ph}_{2} \mathrm{Me}($ octyl)Si $(1 \%, 7)$ & & 7 \\
\hline 24 & Karstedt's catalyst & & & $\mathrm{Ph}_{2} \mathrm{Me}($ octyl)Si (93\%, 928) & & 928 \\
\hline
\end{tabular}

a) Reaction conditions: Neat, r.t., 24 h, Schlenk tube, [silane]:[1-octene] $=1: 2$, $[$ Fe complex]:[NaBHEt $]=1: 20$. b) $\mathrm{mol} \%=[\mathrm{Fe}$ complex $] /[$ silane $] \times 100$. c) Determined by HPLC. The values are based on the initial concentration of hydrosilane. $d)$ Total TON $=$ TON of single-alkylated product $+2 \times$ (TON of double-alkylated product).

found (Table 1, entries 1-4): (i) the iron complexes with $\mathrm{R}=$ $\mathrm{CH}_{3}$ and $\mathrm{CF}_{3}$ produced not only monoalkylated silane but also dialkylated silane, and showed very high catalytic activity (total TON $=10890$ and 12360, respectively), (ii) the iron complexes with $\mathrm{R}=\mathrm{H}$ and ${ }^{t} \mathrm{Bu}$ produced mainly monoalkylated silane (the yield of dialkylated silane was only $1 \%$ ), and the total TON's decreased, $2300(\mathrm{R}=\mathrm{H})$ and $1640\left(\mathrm{R}={ }^{t} \mathrm{Bu}\right)$, compared to those of the iron complexes with $\mathrm{R}=\mathrm{CH}_{3}$ and $\mathrm{CF}_{3}$. For the hydrosilylation reactions with the secondary silane $\mathrm{Ph}_{2} \mathrm{SiH}_{2}$ (Table 1, entries 9-12), the catalytic activities were greater than that with the primary silane $\mathrm{PhSiH}_{3}$ for all the iron complexes screened: total TON $=10890$ to $16040(\mathrm{R}$ $=\mathrm{Me}), 12360$ to $14350\left(\mathrm{R}=\mathrm{CF}_{3}\right), 2300$ to $6480(\mathrm{R}=\mathrm{H})$, and 1640 to $4190\left(\mathrm{R}={ }^{t} \mathrm{Bu}\right)$. The tendencies observed for $\mathrm{PhSiH}_{3}$ ((i) and (ii)) were also observed for $\mathrm{Ph}_{2} \mathrm{SiH}_{2}$. It should be noted that the catalytic activities of iron complexes bearing either an electron-donating (Me) or an electron-withdrawing substituent $\left(\mathrm{CF}_{3}\right)$ are greater than that of the iron complexes with $\mathrm{H}$ on the imino carbon. These results suggest that the catalytic activity is mainly controlled by steric and not by electronic effects of the substituent on the imino carbon. The bulkiness of the substituent on the imino nitrogen also affects the catalytic activity. $\left({ }^{\mathrm{H}} \mathrm{BPI}^{\mathrm{Dipp}, \mathrm{H}}\right) \mathrm{FeBr}_{2}$ showed greater activity than $\left({ }^{\mathrm{H}} \mathrm{BPI}^{\mathrm{Dipp}, \mathrm{Me}}\right) \mathrm{FeBr}_{2}$ and $\left({ }^{\mathrm{H}} \mathrm{BPI}^{\mathrm{Dipp}, \mathrm{CF} 3}\right) \mathrm{FeBr}_{2}$ (Table 1, entries 5-7 and 13-15). This is the opposite tendency observed for $\left({ }^{\mathrm{H}} \mathrm{BPI}^{\mathrm{Mes}, \mathrm{R}}\right) \mathrm{FeBr}_{2}$, implying that the combination of substituents on the imino carbon and imino nitrogen is important. One more point to which we have to pay attention is the distribution of mono- and dialkylated products. The distribution obtained with $\mathrm{PhSiH}_{3}$ catalyzed by $\left({ }^{\mathrm{H}} \mathrm{BPI}^{\mathrm{Mes}, \mathrm{Me}}\right) \mathrm{FeBr}_{2}$ and $\left({ }^{\mathrm{H}} \mathrm{BPI}^{\mathrm{Mes}, \mathrm{CF} 3}\right) \mathrm{FeBr}_{2}$ is similar to that obtained by $\left({ }^{\mathrm{H}} \mathrm{BPI}-\right.$ Dipp,H ${ }^{-} \mathrm{FeBr}_{2}$. In contrast, the distribution obtained with $\mathrm{Ph}_{2} \mathrm{SiH}_{2}$ catalyzed by $\left({ }^{\mathrm{H}} \mathrm{BPI}^{\mathrm{Mes}, \mathrm{Me}}\right) \mathrm{FeBr}_{2}$ and $\left({ }^{\mathrm{H}} \mathrm{BPI}^{\mathrm{Mes}, \mathrm{CF} 3}\right) \mathrm{FeBr}_{2}$ is different from that by $\left({ }^{\mathrm{H}} \mathrm{BPI}^{\mathrm{Dipp}, \mathrm{H}}\right) \mathrm{FeBr}_{2}$. This seems to be an effect from the steric combination of the substituents on the imino carbon and imino nitrogen. The tertiary silane $\mathrm{Ph}_{2} \mathrm{MeSiH}$ also gave hydrosilylation product, but the catalytic activities were low compared to those with primary and secondary silanes (Table 1, entries 17-23).

When Karstedt's catalyst was used under the same reaction conditions (Table 1 , entries 8,16 , and 24), only monoalkylated 
Table 2. NBO atomic charges (qFe, HOMO, and LUMO) and torsion angle.

\begin{tabular}{lllll|lll}
\hline & $\left({ }^{\mathrm{H}} \mathrm{BPI}{ }^{\mathrm{Mes}, \mathrm{R}}\right) \mathrm{Fe}$ & & & & & \\
& $\left(\mathrm{H} \mathrm{BP}^{\mathrm{Dip}, \mathrm{R}}\right) \mathrm{Fe}$ & & \\
& $(\mathrm{R}=\mathrm{H})$ & $(\mathrm{R}=\mathrm{Me})$ & $\left(\mathrm{R}={ }^{t} \mathrm{Bu}\right)$ & $\left(\mathrm{R}=\mathrm{CF}_{3}\right)$ & $(\mathrm{R}=\mathrm{H})$ & $(\mathrm{R}=\mathrm{Me})$ & $\left(\mathrm{R}=\mathrm{CF}_{3}\right)$ \\
\hline$\sigma_{\mathrm{m}}{ }^{\mathrm{a}}$ & 0.00 & -0.07 & -0.10 & 0.43 & 0.00 & -0.07 & 0.43 \\
$\sigma_{\mathrm{p}}{ }^{\mathrm{a}}$ & 0.00 & -0.17 & -0.20 & 0.54 & 0.00 & -0.17 & 0.54 \\
$q_{\mathrm{Fe}}{ }^{\mathrm{b}}$ & $(0.19)$ & 0.44 & 0.43 & 0.46 & 0.42 & 0.47 & 0.48 \\
$\mathrm{HOMO}(\mathrm{eV})^{\mathrm{b}}$ & -3.52 & -3.49 & -3.63 & -3.94 & -3.58 & -3.63 & -4.00 \\
$\mathrm{LUMO}(\mathrm{eV})^{\mathrm{b}}$ & -1.69 & -1.44 & -1.45 & -2.26 & -1.38 & -1.47 & -2.28 \\
$\Delta(\mathrm{eV})^{\mathrm{b}}$ & 1.83 & 2.17 & 2.18 & 1.67 & 2.20 & 2.16 & 1.72 \\
torsion angle $\left({ }^{\circ}\right)^{\mathrm{b}, \mathrm{c}}$ & 0.0 & 88.8 & 85.3 & 87.2 & 49.7 & 89.9 & 88.5 \\
\hline
\end{tabular}

a) Hammett substituent constants. b) B3RYP (SDD/ Fe; 6-31G(d,p)/ C, H, N, F). c) Torsion angle of iminobipyridine unit and aryl ring on the imino nitrogen.

(a) HOMO of $\left({ }^{\mathrm{H}} \mathrm{BPI}^{\mathrm{Mes}, \mathrm{H}}\right) \mathrm{Fe}$

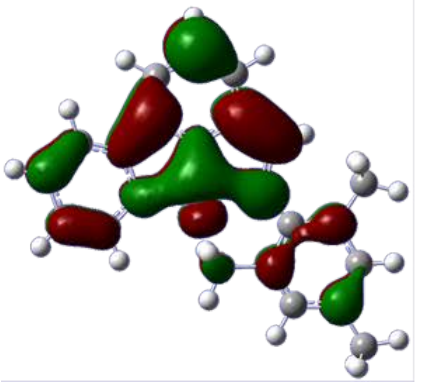

(b) LUMO of $\left({ }^{\mathrm{H}} \mathrm{BPI}^{\mathrm{Mes}, \mathrm{H}}\right) \mathrm{Fe}$

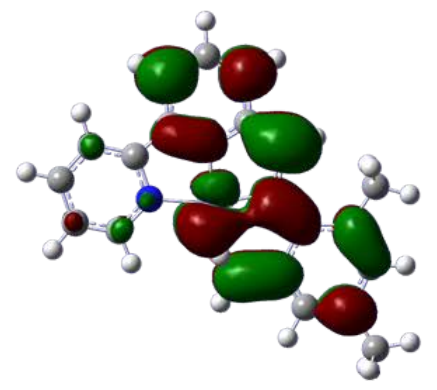

(c) HOMO of $\left({ }^{\mathrm{H}} \mathrm{BPI}^{\mathrm{Mes}, \mathrm{Me}}\right) \mathrm{Fe}$

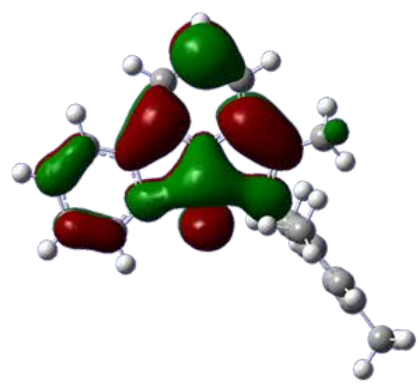

(d) LUMO of $\left({ }^{\mathrm{H}} \mathrm{BPI}^{\mathrm{Mes}, \mathrm{Me}}\right) \mathrm{Fe}$

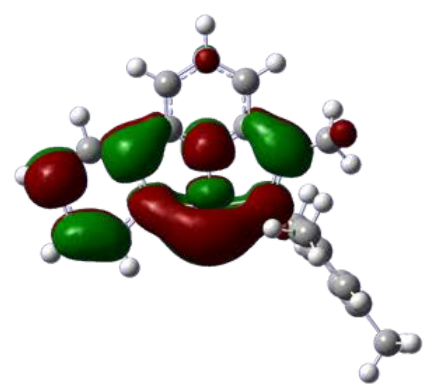

Figure 3. HOMO and LUMO of $\left({ }^{\mathrm{H}} \mathrm{BPI}^{\mathrm{Mes}, \mathrm{R}}\right) \mathrm{Fe}(\mathrm{R}=\mathrm{H}, \mathrm{Me})$.

product was formed with all silanes. Compared to Karstedt's catalyst, the catalytic activity of our iron complexes is slightly lower with the tertiary silane, but much greater with the primary and secondary silanes.

Effect of the Substituent on the Imino Carbon on Catalytic Activity. We previously reported that iminobipyridine derivatives $\left({ }^{\mathrm{R}} \mathrm{BPI}^{\mathrm{Ar}, \mathrm{R}}\right)$ were appropriate ligands for iron and their complexes, after suitable activation, exhibit high hydrosilylation catalytic activity. ${ }^{10}$ The dibromoiron complex $\left({ }^{\mathrm{R}} \mathrm{BPI}^{\mathrm{Ar}, \mathrm{R}}\right) \mathrm{FeBr}_{2}$ was inactive and only after treatment with $\mathrm{NaBHEt}_{3}$, the resulting system showed catalytic activity. Therefore, we proposed that $\left({ }^{\mathrm{R}} \mathrm{BPI}^{\mathrm{Ar}, \mathrm{R}}\right) \mathrm{Fe}$, formed from

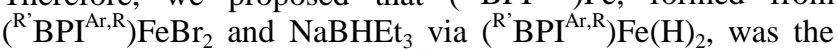
real active species (Scheme 2). ${ }^{10}$ The effect of the substituents ( $\mathrm{R}$ ' and $\mathrm{Ar}$ ) on the catalytic activity was examined and found that the bulkiness of R' and Ar had a dominant effect because of their proximity to the iron active site. How does the substituent on the imino carbon (R), being far from the active site, affect the catalytic activity? In this case, both electronic and steric effects had to be considered.

Scheme 2. Iron complexes with an iminobipyridine derivative ligand
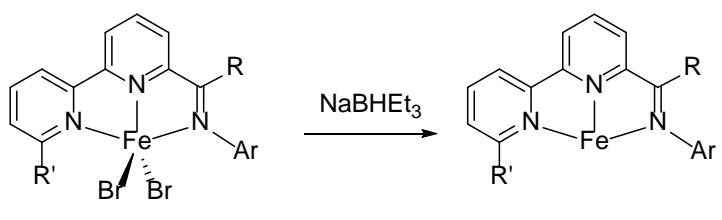

$\left({ }^{\mathrm{R}} \mathrm{BPI}^{\mathrm{Ar}, \mathrm{R}}\right) \mathrm{FeBr} 2$

$\left({ }^{\mathrm{R}} \mathrm{BPI}{ }^{\mathrm{Ar}, \mathrm{R}}\right) \mathrm{Fe}$
The order of the electron-donating ability of the substituent on the imino carbon is $\mathrm{CF}_{3}<<\mathrm{H}<\mathrm{Me}<{ }^{t} \mathrm{Bu}$. ${ }^{15}$ The observed catalytic activities (shown in Table 1) did not match this order. For example, the catalytic activity with $\mathrm{PhSiH}_{3}$ for $\left({ }^{\mathrm{H}} \mathrm{BPI}^{\mathrm{Mes}, \mathrm{Me}}\right) \mathrm{FeBr}_{2}$ (bearing an electron-donating group) is similar to that for $\left({ }^{\mathrm{H}} \mathrm{BPI}^{\mathrm{Mes}, \mathrm{CF} 3}\right) \mathrm{FeBr}_{2}$ (bearing an electronwithdrawing group) (Table 1 , entries 2 and 4), and much greater than that of $\left({ }^{\mathrm{H}} \mathrm{BPI}^{\mathrm{Mes}, \mathrm{H}}\right) \mathrm{FeBr}_{2}$ (Table 1, entry 1).

To understand the effect of the substituent on the imino carbon on the catalytic activity, the proposed active spices ( ${ }^{\mathrm{H}} \mathrm{BPI}-$ $\left.{ }^{\mathrm{Ar}, \mathrm{R}}\right) \mathrm{Fe}$ were subjected to density functional theory (DFT) studies. ${ }^{13}$ All calculations were performed under B3LYP ${ }^{14-16}$, $\mathrm{SDD}^{17}$ (Fe), 6-31G(d,p) (C, H, N, F) level using Gaussian 09 software. The natural bond orbital (NBO) analysis data ${ }^{18}$ is listed in Table 2. The atomic natural charges on the iron atom in $\left({ }^{\mathrm{H}} \mathrm{BPI}^{\mathrm{Ar}, \mathrm{R}}\right) \mathrm{Fe}$ ranged from 0.42 to 0.48 , except in $\left({ }^{\mathrm{H}} \mathrm{BPI}^{\mathrm{Mes}, \mathrm{H}}\right) \mathrm{Fe}$, and did not significantly changed with the variation of the substituent on the imino carbon. The HOMO and LUMO energy levels do not seem to explain the observed order of reactivity.

The optimized structures and HOMO and LUMO of $\left({ }^{\mathrm{H}} \mathrm{BPI}^{\mathrm{Mes}, \mathrm{H}}\right) \mathrm{Fe}$ and $\left({ }^{\mathrm{H}} \mathrm{BPI}^{\mathrm{Mes}, \mathrm{Me}}\right) \mathrm{Fe}$ are depicted in Figure 3 . The most notorious difference is the orientation of the Mes ring. The iminobipyridine unit and the Mes ring are coplanar in $\left({ }^{\mathrm{H}} \mathrm{BPI}^{\mathrm{Mes}, \mathrm{H}}\right) \mathrm{Fe}$, with a torsion angle of $0.0^{\circ}$ between the rings (Table 2). This is probably due to the extension of the $\pi$ system. In contrast, the BPI unit and the Mes ring are orthogonal in $\left({ }^{\mathrm{H}} \mathrm{BPI}^{\mathrm{Mes}, \mathrm{Me}}\right) \mathrm{Fe}$ (torsion angle $=88.8^{\circ}$, Table 2 ). This is due to the steric repulsion between the Mes group on the imino nitrogen and the Me group on the imino carbon. The torsion 
Table 3. Hydrosilylation of functionalized olefins catalyzed by $\left({ }^{\mathrm{H}} \mathrm{BPI}^{\mathrm{Mes}, \mathrm{Me}}\right) \mathrm{FeBr}_{2}$ and $\left({ }^{\mathrm{H}} \mathrm{BPI}^{\mathrm{Dipp}, \mathrm{H}}\right) \mathrm{FeBr}_{2}{ }^{\mathrm{a}}$

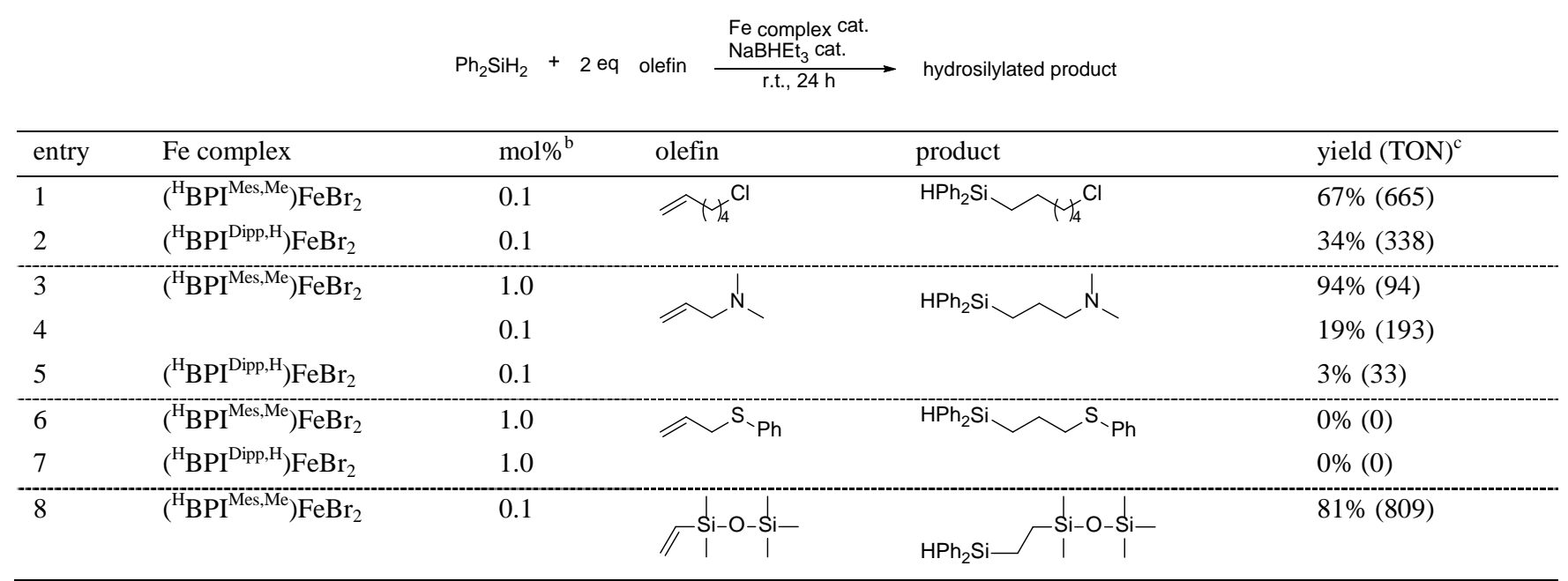

a) Reaction conditions: Neat, r.t., 24 h, Schlenk tube, [silane]:[olefin] $=1: 2$, $\left[\right.$ Fe complex]:[NaBHEt $\left.{ }_{3}\right]=1: 20$. b) mol\% $=[$ Fe complex]/[silane] $\times 100$. c) Isolated yield. The values are based on the initial concentration of hydrosilane.

Table 4. Hydrosilylation of 1-octene with various silanes catalyzed by $\left({ }^{\mathrm{H}} \mathrm{BPI}^{\mathrm{Mes}, \mathrm{Me}}\right) \mathrm{FeBr}_{2}{ }^{\mathrm{a}}$

$$
\text { silane }+2 \text { eq 1-octene } \frac{\left({ }^{\mathrm{N}} \mathrm{NaBHEt}_{3}\right. \text { cat. }}{\text { r.t., } 24 \mathrm{~h}} \text { hydrosilylated product }
$$

\begin{tabular}{|c|c|c|c|c|c|}
\hline entry & silane & $\mathrm{mol}^{\mathrm{b}}$ & 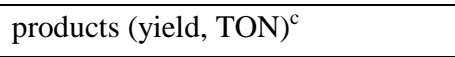 & & total $\mathrm{TON}^{\mathrm{d}}$ \\
\hline 1 & $\mathrm{PhSiH}_{3}$ & 0.1 & $\mathrm{Ph}($ octyl $) \mathrm{SiH}_{2}(0 \%, 0)$ & $\mathrm{Ph}(\text { octyl })_{2} \mathrm{SiH}(93 \%, 930)$ & 1860 \\
\hline 2 & & 0.01 & $\mathrm{Ph}$ (octyl) $\mathrm{SiH}_{2}(56 \%, 5610)$ & $\mathrm{Ph}(\text { octyl })_{2} \mathrm{SiH}(26 \%, 2640)$ & 10890 \\
\hline 3 & $\mathrm{Ph}_{2} \mathrm{SiH}_{2}$ & 0.1 & $\mathrm{Ph}_{2}$ (octyl)SiH $(0 \%, 0)$ & $\mathrm{Ph}_{2}$ (octyl) $)_{2} \mathrm{Si}(91 \%, 909)$ & 1818 \\
\hline 4 & & 0.01 & $\mathrm{Ph}_{2}$ (octyl)SiH $(31 \%, 3120)$ & $\mathrm{Ph}_{2}$ (octyl) $)_{2} \mathrm{Si}(65 \%, 6460)$ & 16040 \\
\hline 5 & $\mathrm{PhMeSiH}_{2}$ & 0.1 & $\mathrm{PhMe}($ octyl)SiH $(0 \%, 0)$ & $\mathrm{PhMe}(\mathrm{octyl})_{2} \mathrm{Si}(70 \%, 703)$ & 1406 \\
\hline 6 & & 0.01 & PhMe(octyl)SiH (64\%, 6350) & $\mathrm{PhMe}(\text { octyl })_{2} \mathrm{Si}(0.5 \%, 50)$ & 6450 \\
\hline $7^{\mathrm{e}}$ & $\mathrm{Et}_{2} \mathrm{SiH}_{2}$ & 0.1 & $\mathrm{Et}_{2}$ (octyl) $\mathrm{SiH}(68 \%, 675)$ & $\mathrm{Et}_{2}(\mathrm{octyl})_{2} \mathrm{Si}(26 \%, 257)$ & 1189 \\
\hline 8 & $\mathrm{Ph}_{3} \mathrm{SiH}$ & 0.1 & $\mathrm{Ph}_{3}(\mathrm{octyl}) \mathrm{Si}(0 \%, 0)$ & & 0 \\
\hline 9 & $\mathrm{Ph}_{2} \mathrm{MeSiH}$ & 0.1 & $\mathrm{Ph}_{2} \mathrm{Me}($ octyl)Si $(80 \%, 795)$ & & 795 \\
\hline 10 & & 0.01 & $\mathrm{Ph}_{2} \mathrm{Me}($ octyl)Si $(45 \%, 4520)$ & & 4520 \\
\hline 11 & $\mathrm{PhMe}_{2} \mathrm{SiH}$ & 0.1 & $\mathrm{PhMe}_{2}$ (octyl)Si $(95 \%, 951)$ & & 951 \\
\hline 12 & & 0.01 & $\mathrm{PhMe}_{2}$ (octyl)Si (39\%, 3870) & & 3870 \\
\hline $13^{\mathrm{e}}$ & $\mathrm{Et}_{3} \mathrm{SiH}$ & 0.1 & $\mathrm{Et}_{3}$ (octyl)Si $(10 \%, 102)$ & & 102 \\
\hline $14^{\mathrm{e}}$ & $\left(\mathrm{Me}_{3} \mathrm{SiO}\right) \mathrm{Me}_{2} \mathrm{SiH}$ & 0.1 & $\left(\mathrm{Me}_{3} \mathrm{SiO}\right) \mathrm{Me}_{2}$ (octyl)Si $(74 \%, 739)$ & & 739 \\
\hline $15^{\mathrm{e}}$ & $\left(\mathrm{Me}_{3} \mathrm{SiO}\right)_{2} \mathrm{MeSiH}$ & 0.1 & $\left(\mathrm{Me}_{3} \mathrm{SiO}\right)_{2} \mathrm{Me}($ octyl $) \mathrm{Si}(79 \%, 791)$ & & 791 \\
\hline $16^{\mathrm{e}}$ & $\left(\mathrm{HMe}_{2} \mathrm{Si}\right)_{2} \mathrm{O}$ & 0.1 & $\mathrm{Me}_{2}$ (octyl)SiOSiMe ${ }_{2} \mathrm{H}(-\%,-)$ & $\left(\mathrm{Me}_{2} \text { (octyl)Si }\right)_{2} \mathrm{O}(46 \%, 457)$ & - \\
\hline
\end{tabular}

a) Reaction conditions: Neat, r.t., 24 h, Schlenk tube, [silane]:[olefin] = 1:2, [Fe complex]:[NaBHEt $\left.{ }_{3}\right]=1: 20$. b) mol\% $=[$ Fe complex $] /[$ silane $] \times 100$. c) Determined by HPLC. The values are based on the initial concentration of hydrosilane. d) Total TON $=$ TON of single-alkylated product $+2 \times$ (TON of double-alkylated product). e) Isolated yield.

angles in $\left({ }^{\mathrm{H}} \mathrm{BPI}^{\mathrm{Mes}, \mathrm{BB}}\right) \mathrm{Fe}$ and $\left({ }^{\mathrm{H}} \mathrm{BPI}^{\mathrm{Mes}, \mathrm{CF} 3}\right) \mathrm{Fe}$ are $85.3^{\circ}$ and $87.2^{\circ}$, respectively (Table 2 ). When there is no steric repulsion $(\mathrm{R}=\mathrm{H})$, the Mes ring adopts a coplanar orientation in order to extend the $\pi$ conjugation. In such orientation a Me group on the Mes is brought towards the vacant site of the $\mathrm{Fe}$, and blocks the iron active site. If there is steric repulsion between $\mathrm{R}$ and Ar, the aryl ring adopts an upright position, which leaves the iron active site open for the substrate to approach.
Therefore, the catalytic activity of $\left({ }^{\mathrm{H}} \mathrm{BPI}^{\mathrm{Mes}, \mathrm{H}}\right) \mathrm{Fe}$ is lower than those of $\left({ }^{\mathrm{H}} \mathrm{BPI}^{\mathrm{Mes}, \mathrm{Me}}\right) \mathrm{Fe}$ and $\left({ }^{\mathrm{H}} \mathrm{BPI}^{\mathrm{Mes}, \mathrm{CF} 3}\right) \mathrm{Fe}$. The structural orientation in $\left({ }^{\mathrm{H}} \mathrm{BPI}^{\mathrm{Dipp}, \mathrm{R}}\right) \mathrm{Fe}$ is different from that of $\left({ }^{\mathrm{H}} \mathrm{BPI}^{\mathrm{Mes}, \mathrm{R}}\right) \mathrm{Fe}$. The torsion angle in $\left({ }^{\mathrm{H}} \mathrm{BPI}^{\mathrm{Dipp}, \mathrm{H}}\right) \mathrm{Fe}$ is about $50^{\circ}$, the Dipp ring adopts an upright position, and the $i$-Pr group in the Dipp does not block the active iron site. This is presumably the reason for a high TON number for $\left({ }^{\mathrm{H}} \mathrm{BPI}^{\mathrm{Dipp}, \mathrm{H}}\right) \mathrm{FeBr}_{2}$. Therefore, the substituent (R) on the imino carbon may control the orientation of the aromatic (Ar) ring on the imino nitrogen. 
If $\mathrm{R}=\mathrm{H}$ and $\mathrm{Ar}=$ Mes, the Mes ring adopts a coplanar orientation and blocks the approach of the substrate to the active iron site, whereas if $\mathrm{R}=\mathrm{CH}_{3}, \mathrm{CF}_{3},{ }^{t} \mathrm{Bu}$ and $\mathrm{Ar}=\mathrm{Mes}$, Dipp, or $\mathrm{R}=\mathrm{H}$ and $\mathrm{Ar}=$ Dipp, the $\mathrm{Ar}$ ring takes an upright position leaving open the active iron site, and resulting in high catalytic activity and to the same extent for $\mathrm{R}=\mathrm{CH}_{3}$ and $\mathrm{CF}_{3}$.

Hydrosilylation of Functionalized Olefins. It is known that transition-metal catalysts are susceptible to catalyst poisons such as $\mathrm{Cl}-, \mathrm{N}$-, or S-containing compounds. We next examined the hydrosilylation of several functionalized olefins with $\mathrm{Ph}_{2} \mathrm{SiH}_{2}$ catalyzed by $\left({ }^{\mathrm{H}} \mathrm{BPI}^{\mathrm{Mes}, \mathrm{Me}}\right) \mathrm{FeBr}_{2}$. The results of this study, together with those for $\left({ }^{\mathrm{H}} \mathrm{BPI}^{\mathrm{Dipp}, \mathrm{H}}\right) \mathrm{FeBr}_{2}$ from our previous work, ${ }^{10}$ are summarized in Table 3. 6-Chloro-1hexene and $N, N$-dimethylallylamine were converted into the corresponding hydrosilylated products in the presence of 0.1 mol\% of $\left({ }^{\mathrm{H}} \mathrm{BPI}^{\mathrm{Mes}, \mathrm{Me}}\right) \mathrm{FeBr}_{2}$ (Table 3, entries 1 and 4). The yield of hydrosilylated $N, N$-dimethylallylamine increased when $1.0 \mathrm{~mol} \%$ of $\left({ }^{\mathrm{H}} \mathrm{BPI}^{\mathrm{Mes}, \mathrm{Me}}\right) \mathrm{FeBr}_{2}$ was used (Table 3 , entry 3 ). The catalytic activities for $\mathrm{Cl}$ - and $\mathrm{N}$-containing olefins were greater for $\left({ }^{\mathrm{H}} \mathrm{BPI}^{\mathrm{Mes}, \mathrm{Me}}\right) \mathrm{FeBr}_{2}$ than for $\left({ }^{\mathrm{H}} \mathrm{BPI}^{\mathrm{Dipp}, \mathrm{H}}\right) \mathrm{FeBr}_{2}$. In contrast, hydrosilylation of allyl phenyl sulfide did not occur, presumably caused by the coordination of the sulfur of the substrate to the catalytically active iron species, which reduces or destroys the catalytic activity (Table 3, entries 6 and 7). Vinylpentametyldisiloxane was converted to the corresponding monoalkylated silane by $\left({ }^{\mathrm{H}} \mathrm{BPI}^{\mathrm{Mes}, \mathrm{Me}}\right) \mathrm{FeBr}_{2}$ (Table 3, entry 8).

Hydrosilylation of 1-Octene with Various Hydrosilanes Catalyzed by $\left({ }^{\mathrm{H}} \mathbf{B P I}^{\mathrm{Mes}, \mathbf{M e}}\right) \mathbf{F e B r}_{2}$. We then investigated the influence of various hydrosilanes on the hydrosilylation of 1octene in the presence of $\left({ }^{\mathrm{H}} \mathrm{BPI}^{\mathrm{Mes}, \mathrm{Me}}\right) \mathrm{FeBr}_{2}$. The results are summarized in Table 4, and include some results from Table 1. When 0.1 mol\% of $\left({ }^{\mathrm{H}} \mathrm{BPI}^{\mathrm{Mes}, \mathrm{Me}}\right) \mathrm{FeBr}_{2}$ was used, $\mathrm{PhSiH}_{3}$, $\mathrm{Ph}_{2} \mathrm{SiH}_{2}$, and $\mathrm{PhMeSiH}_{2}$ were completely converted into the corresponding dialkylated silanes (Table 4, entries 1, 3, and 5). In contrast, both, mono and dialkylated silanes were formed when the amount of catalyst was reduced from $0.1 \mathrm{~mol} \%$ to $0.01 \mathrm{~mol} \%$ (Table 4, entries 2, 4, and 6). With $\mathrm{Et}_{2} \mathrm{SiH}_{2}$, both of mono and dialkylated silanes were formed even in the presence of $0.1 \mathrm{~mol} \%$ of iron complex (Table 4, entry 7). While no reaction occurred with $\mathrm{Ph}_{3} \mathrm{SiH}$ (Table 4, entry 8), other tertiary silanes, such as $\mathrm{Ph}_{2} \mathrm{MeSiH}, \mathrm{PhMe}_{2} \mathrm{SiH}$, and $\mathrm{Et}_{3} \mathrm{SiH}$, were converted into monoalkylated silanes (Table 4, entries 9, 11, and 13). It should be noted that our catalytic system could convert $\mathrm{Ph}_{2} \mathrm{MeSiH}$ and $\mathrm{PhMe}_{2} \mathrm{SiH}$ into the corresponding hydrosilylated products in $80 \%$ and $95 \%$, respectively, despite the fact that hydrosilylation of olefins with tertiary silanes is known to be difficult. These reactions occurred in the presence of only 0.01 mol\% of iron complex (Table 4, entries 10 and 12). The hydrosilylation reactions with silanes bearing siloxyl groups, such as $\left(\mathrm{Me}_{3} \mathrm{SiO}\right) \mathrm{Me}_{2} \mathrm{SiH}$ and $\left(\mathrm{Me}_{3} \mathrm{SiO}\right)_{2} \mathrm{MeSiH}$, proceeded smoothly in the presence of $0.1 \mathrm{~mol} \%$ of iron complex (Table 4, entries 14 and 15). When $\left(\mathrm{HMe}_{2} \mathrm{Si}\right)_{2} \mathrm{O}$ was used, both, monoalkylated silane and dialkylated silane were formed (Table 4, entry 16), though $\mathrm{Me}_{2}$ (octyl)SiOSiMe${ }_{2} \mathrm{H}$ could not be isolated because of the difficulty of removing an impurity.

Effect of the Iron Catalyst Concentration on the Catalytic Activity. Table 1 shows that $\left({ }^{\mathrm{H}} \mathrm{BPI}^{\mathrm{Mes}, \mathrm{Me}}\right) \mathrm{FeBr}_{2}$ has a relatively high catalytic activity for primary, secondary, and tertiary hydrosilanes compared to other iron catalysts and especially for $\mathrm{Ph}_{2} \mathrm{SiH}_{2}$, for which the highest TON was observed. Therefore, we examined the effect of reducing the amount of $\left({ }^{\mathrm{H}} \mathrm{BPI}^{\mathrm{Mes}, \mathrm{Me}}\right) \mathrm{FeBr}_{2}$ on the TON. Thus, reactions of $\mathrm{Ph}_{2} \mathrm{SiH}_{2}$ with 1-octene were performed in the presence of $0.01,0.003$, 0.002, and $0.001 \mathrm{~mol} \%$ of $\left({ }^{\mathrm{H}} \mathrm{BPI}^{\mathrm{Mes}, \mathrm{Me}}\right) \mathrm{FeBr}_{2}$.

$\mathrm{Ph}_{2} \mathrm{SiH}_{2}$ and 1-octene, in a 1:2 molar ratio and $0.01 \mathrm{~mol} \%$ of $\left({ }^{\mathrm{H}} \mathrm{BPI}^{\mathrm{Mes}, \mathrm{Me}}\right) \mathrm{FeBr}_{2}$, were placed in a Schlenk tube. $\mathrm{NaBHEt}_{3}$ $(0.2 \mathrm{~mol} \%)$ was added to the suspension with stirring at room temperature, which resulted in the formation of a homogeneous solution within $5 \mathrm{~min}$. The solution was stirred without any temperature control for $10 \mathrm{~min}$, and then separated into several portions. An appropriate amount of a mixture of $\mathrm{Ph}_{2} \mathrm{SiH}_{2}$ and 1-octene, in a 1:2 molar ration, was added to each portion to dilute the contents of the iron species to 0.003 , 0.002 , and $0.001 \mathrm{~mol} \%$. The resulting solutions were stirred for $24 \mathrm{~h}$, and the yields of hydrosilylated products determined by HPLC. The results are summarized in Scheme 3. In all cases, the monoalkylated silane was exclusively formed. The TONs were 18000,34000 , and 42000 for iron catalyst concentration of $0.003,0.002$, and $0.001 \mathrm{~mol} \%$, respectively. To our knowledge, 42000 TON is the highest reported value in an iron-complex catalyzed olefin hydrosilylation.

\section{CONCLUSION}

We have prepared a series of ketimine-type iminobipyridine iron complexes. When these iron complexes are activated by $\mathrm{NaBHEt}_{3}$, they exhibit high catalytic activities for the hydrosilylation of terminal olefins with primary, secondary, and tertiary silanes. The iron catalyst converts primary or secondary silanes into not only monoalkylated silanes but also dialkylated silanes. The alkylation of silanes by olefin hydrosilylation is assumed to proceed stepwise, i.e., the monoalkylated product forms first, followed by formation of the dialkylated product. Therefore, controlling each reaction rate is important for the selective formation of these alkylated silanes, and can be achieved by changing the amount of the iron catalyst. These iron complexes can be handled under ambient conditions prior to the formation of the active species.

\section{EXPERIMENTAL SECTION}

All reactions were carried out under a nitrogen atmosphere using Schlenk techniques. Hexane, toluene, diethyl ether, and THF were distilled from sodium and benzophenone prior to use and stored under nitrogen. 2-Tributylstannylpyridine, $\left({ }^{\mathrm{H}} \mathrm{BPI}^{\mathrm{Mes}, \mathrm{H}}\right) \mathrm{FeBr}_{2}$, and $\left({ }^{\mathrm{H}} \mathrm{BPI}-\right.$ $\left.{ }^{\mathrm{Dipp}, \mathrm{H}}\right) \mathrm{FeBr}_{2}$ were synthesized according to literature methods. ${ }^{10}$ All other chemicals were purchased from commercial sources. ${ }^{1} \mathrm{H}$ and ${ }^{13} \mathrm{C}\left\{{ }^{1} \mathrm{H}\right\}$ NMR spectra were recorded on a JEOL JNM-AL 400 spectrometer. The residual peaks of the solvent were used as internal standard. NMR measurements of all iron complexes were difficult due to their poor solubility in common solvents. IR spectra were recorded on a JASCO FTIR-6200 spectrum. GC-MS measurements were conducted on a SHIMADZU Gas Chromatograph linked to a QP2010 Plus mass spectrometer.

HPLC analyses were performed on a Shimadzu Prominence UFLC (LC-20 series) chromatograph using a Cosmosil 5C18-MS-II column $(250 \times 4.6 \mathrm{~mm})$. The instrument was set to an injection volume of 5 $\mu \mathrm{L}$. Acetonitrile $(100 \%)$ was used as the carrier phase with a flow rate of $1.0 \mathrm{~mL} / \mathrm{min}$. The column temperature was kept at $40^{\circ} \mathrm{C}$. Quantification was performed using the calibration curves of peak area versus concentration, covering the relevant concentration range, using pure hydrosilylation products. The reaction mixture was exposed to air, diluted to the appropriate concentration (within the calibration range), and analyzed by HPLC.

6-Bromo-2,2'-bipyridine (1): A mixture of 2,6-dibromopyridine (74.0 g, $312 \mathrm{mmol})$, 2-tributylstannylpyridine (115 g, $312 \mathrm{mmol})$, and $\mathrm{Pd}\left(\mathrm{PPh}_{3}\right)_{4}(18.5 \mathrm{~g}, 16.0 \mathrm{mmol})$ in toluene $(120 \mathrm{~mL})$ was refluxed overnight. After the mixture was allowed to cool to room temperature, 
the solvent was removed under reduced pressure. The crude product was brined in $\mathrm{CHCl}_{3}(630 \mathrm{~mL})$ and $6 \mathrm{M} \mathrm{HCl}$ aqueous solution $(630$ $\mathrm{mL})$. The aqueous layer was washed by $\mathrm{CHCl}_{3}(630 \mathrm{~mL} \times 2)$ and the aqueous layer was added dropwise to a $10 \mathrm{M} \mathrm{NaOH}$ aqueous solution $(420 \mathrm{~mL})$ at $0{ }^{\circ} \mathrm{C}$. Part of the product crystallized out of the solution and was collected by filtration. The product in the filtrate was extracted with $\mathrm{CHCl}_{3}(630 \mathrm{~mL})$. The crude product collected from the filtration was combined and dissolved in the extracted $\mathrm{CHCl}_{3}$ and dried over anhydrous $\mathrm{Na}_{2} \mathrm{SO}_{4}$. After the solvent was removed under reduced pressure, the resulting solid was purified by column chromatograph (Silica, AcOEt/hexane =1/9). The target product was obtained as a white powder in $62 \%$ yield. ${ }^{1} \mathrm{H}$ NMR $\left(400 \mathrm{MHz}, \mathrm{CDCl}_{3}\right): \delta(\mathrm{ppm})$ $=7.32\left(\mathrm{dd}, 1 \mathrm{H},{ }^{3} J_{H H}=4.8\right.$ and $\left.7.6 \mathrm{~Hz}\right), 7.48\left(\mathrm{~d}, 1 \mathrm{H},{ }^{3} J_{\mathrm{HH}}=7.8 \mathrm{~Hz}\right)$, $7.66\left(\mathrm{t}, 1 \mathrm{H},{ }^{3} J_{\mathrm{HH}}=7.8 \mathrm{~Hz}\right), 7.81\left(\mathrm{td}, 1 \mathrm{H},{ }^{3} J_{\mathrm{HH}}=7.9 \mathrm{~Hz}\right.$ and $\left.{ }^{4} J_{\mathrm{HH}}=1.5\right)$, $8.37\left(\mathrm{~d}, 1 \mathrm{H},{ }^{3} J_{\mathrm{HH}}=7.7 \mathrm{~Hz}\right), 8.49\left(\mathrm{~d}, 1 \mathrm{H},{ }^{3} J_{\mathrm{HH}}=8.2 \mathrm{~Hz}\right), 8.66(\mathrm{bd}, 1 \mathrm{H}$, $\left.{ }^{3} J_{\mathrm{HH}}=4.4 \mathrm{~Hz}\right) \cdot{ }^{13} \mathrm{C}\left\{{ }^{1} \mathrm{H}\right\}$ NMR $\left(100 \mathrm{MHz}, \mathrm{CDCl}_{3}\right): \delta(\mathrm{ppm})=119.84$, 121.62 , 124.40, 128.12, 137.15, 139.36, 141.72, 149.34, 154.61, 157.46. GC-MS (EI): 236 (44), 234 (46), 155 (100).

1-[2,2'-Bipyridin]-6-yl-ethanone (2): The compound was prepared according to the published procedure with some modifications. ${ }^{19}{ }^{n} \mathrm{BuLi}$ (2.65 $\mathrm{M}$ in hexane, $\left.26.5 \mathrm{~mL}, 70.2 \mathrm{mmol}\right)$ was added dropwise to a solution of $\mathbf{1}(15.0 \mathrm{~g}, 63.8 \mathrm{mmol})$ in a mixture of ether $(45 \mathrm{~mL})$, hexane $(23 \mathrm{~mL})$, and THF $(23 \mathrm{~mL})$ for $30 \mathrm{~min}$ at $-78{ }^{\circ} \mathrm{C}$. After stirring for a further $30 \mathrm{~min}$ at $-78^{\circ} \mathrm{C}, N, N$-dimethylacetamide (12.0 $\mathrm{mL}, 128 \mathrm{mmol}$ ) was slowly added during $1 \mathrm{~min}$ at $-78^{\circ} \mathrm{C}$. The mixture was cooled to below $-80^{\circ} \mathrm{C}$, and then warmed to room temperature. The reaction was quenched with $\mathrm{H}_{2} \mathrm{O}(45 \mathrm{~mL})$, and then extracted with AcOEt $(90 \mathrm{~mL} \times 5)$. The organic fractions were combined and dried over $\mathrm{Na}_{2} \mathrm{SO}_{4}$. The solvent was removed under reduced pressure. The crude product was purified by washing with hexane or by Kugelrohr distillation $\left(140{ }^{\circ} \mathrm{C}, 170 \mathrm{~Pa}\right)$. The target product was obtained as a brown powder in $89 \%$ yield. ${ }^{1} \mathrm{H}$ NMR (400 $\left.\mathrm{MHz}, \mathrm{CDCl}_{3}\right): \delta(\mathrm{ppm})=2.84(\mathrm{~s}, 3 \mathrm{H}), 7.36\left(\mathrm{bt}, 1 \mathrm{H},{ }^{3} J_{\mathrm{HH}}=5.9 \mathrm{~Hz}\right)$, $7.87\left(\mathrm{bt}, 1 \mathrm{H},{ }^{3} J_{\mathrm{HH}}=8.1 \mathrm{~Hz}\right), 7.96\left(\mathrm{t}, 1 \mathrm{H},{ }^{3} J_{\mathrm{HH}}=7.8 \mathrm{~Hz}\right), 8.05(\mathrm{~d}, 1 \mathrm{H}$, $\left.{ }^{3} J_{H H}=7.6 \mathrm{~Hz}\right), 8.53\left(\mathrm{~d}, 1 \mathrm{H},{ }^{3} J_{\mathrm{HH}}=8.0 \mathrm{~Hz}\right), 8.62\left(\mathrm{~d}, 1 \mathrm{H},{ }^{3} J_{H H}=7.9\right.$ $\mathrm{Hz}$ ), 8.70 (bd, $\left.1 \mathrm{H},{ }^{3} J_{\mathrm{HH}}=4.0 \mathrm{~Hz}\right) .{ }^{13} \mathrm{C}\left\{{ }^{1} \mathrm{H}\right\} \mathrm{NMR}\left(100 \mathrm{MHz}, \mathrm{CDCl}_{3}\right.$ ): $\delta(\mathrm{ppm})=25.86,121.26,121.59,124.26,124.42,137.13,137.95$, 149.38, 153.10, 155.53, 155.56, 200.41. GC-MS (EI): 198 (60), 170 (51), 155 (100).

2,2,2,-Trifluoro-1-[2,2'-bipyridin]-6-yl-ethanone (3): The compound was prepared according to the published procedure with some modifications. ${ }^{19} \mathrm{n} \mathrm{BuLi}(2.65 \mathrm{M}$ in hexane, $14.0 \mathrm{~mL}, 35.2 \mathrm{mmol})$ was added dropwise to a solution of $\mathbf{1}(7.52 \mathrm{~g}, 32.0 \mathrm{mmol})$ in a mixture of ether $(23 \mathrm{~mL})$, hexane $(12 \mathrm{~mL})$, and THF $(12 \mathrm{~mL})$ for $30 \mathrm{~min}$ at $78{ }^{\circ} \mathrm{C}$. After stirring for a further $30 \mathrm{~min}$ at $-78{ }^{\circ} \mathrm{C}, 2,2,2$-trifluoro$\mathrm{N}, \mathrm{N}$-dimethylacetamide $(7.2 \mathrm{~mL}, 64.0 \mathrm{mmol})$ was slowly added during $1 \mathrm{~min}$ at $-78{ }^{\circ} \mathrm{C}$. The mixture was cooled to below $-80^{\circ} \mathrm{C}$, and then the reaction mixture was warmed to room temperature. The reaction was quenched with $\mathrm{H}_{2} \mathrm{O}(75 \mathrm{~mL})$, and then extracted with AcOEt $(150 \mathrm{~mL} \times 5)$. The organic fractions were combined and dried over $\mathrm{Na}_{2} \mathrm{SO}_{4}$. The solvent was removed under reduced pressure. The crude product was purified by Kugelrohr distillation $\left(120^{\circ} \mathrm{C}, 140 \mathrm{~Pa}\right)$. The target product was obtained as a brownish white powder in $54 \%$ yield. The product was contaminated with traces of an unknown impurity. ${ }^{1} \mathrm{H}$ NMR $\left(400 \mathrm{MHz}, \mathrm{CDCl}_{3}\right): \delta(\mathrm{ppm})=7.38(\mathrm{~m}, 1 \mathrm{H}), 7.87(\mathrm{qd}, 1 \mathrm{H}$, ${ }^{5} J_{H F}=1.6$ and $\left.{ }^{3} J_{H H}=7.8 \mathrm{~Hz}\right), 8.05\left(\mathrm{t}, 1 \mathrm{H},{ }^{3} J_{H H}=7.8 \mathrm{~Hz}\right), 8.17$ (dd, $1 \mathrm{H},{ }^{3} J_{\mathrm{HH}}=0.9$ and $\left.7.8 \mathrm{~Hz}\right), 8.54\left(\mathrm{bd}, 1 \mathrm{H},{ }^{3} \mathrm{~J}_{\mathrm{HH}}=7.8 \mathrm{~Hz}\right), 8.71 \mathrm{bt}, 1 \mathrm{H}$, $\left.{ }^{3} J_{\mathrm{HH}}=5.8 \mathrm{~Hz}\right), 8.77\left(\mathrm{dd}, 1 \mathrm{H},{ }^{3} \mathrm{~J}_{\mathrm{HH}}=0.7\right.$ and $\left.8.2 \mathrm{~Hz}\right) .{ }^{13} \mathrm{C}\left\{{ }^{1} \mathrm{H}\right\} \mathrm{NMR}$ $\left(100 \mathrm{MHz}, \mathrm{CDCl}_{3}\right): \delta(\mathrm{ppm})=92.20\left(\mathrm{q},{ }^{2} J_{\mathrm{CF}}=32.59 \mathrm{~Hz}\right), 121.66$, $124.72,124.77,125.98,137.39,138.28,147.92,149.31,154.56$, 156.22, 180.78 (q, ${ }^{2} J_{C F}=34.05 \mathrm{~Hz}$ ). GC-MS (EI): 252 (36), 183 (20), 155 (100).

2,2-Dimethyl-1-[2,2'-bipyridin]-6-yl-1-propanone (4): The compound was prepared according to the published procedure with some modifications. $^{20}$ To a suspension of sodium hydride $(7.80 \mathrm{~g}, 195$ $\mathrm{mmol})$ in THF $(550 \mathrm{~mL})$ below $0{ }^{\circ} \mathrm{C}$ was added a solution of $2(4.29 \mathrm{~g}$, $21.7 \mathrm{mmol})$ in THF (43.0 $\mathrm{mL})$ dropwise. The reaction mixture was allowed to warm to room temperature and stirred for 3 hours before recooling to $0{ }^{\circ} \mathrm{C}$. Iodomethane $(13.5 \mathrm{~mL}, 217 \mathrm{mmol})$ was added dropwise and the reaction mixture was stirred at room temperature overnight. Excess sodium hydride was quenched with $\mathrm{H}_{2} \mathrm{O}(70.0 \mathrm{~mL})$ and AcOEt $(70.0 \mathrm{~mL})$. The organic fraction was collected and dried over $\mathrm{Na}_{2} \mathrm{SO}_{4}$. The solvent was removed under reduced pressure. NMR examination of the crude product showed that it was a mixture of triand dialkylated ketone. This crude material was resubjected to the initial reaction conditions, first by dropwise addition to a suspension of sodium hydride $(7.80 \mathrm{~g}, 195 \mathrm{mmol})$ in THF $(550 \mathrm{~mL})$ below $0{ }^{\circ} \mathrm{C}$, then after stirring at room temperature, iodomethane $(13.5 \mathrm{~mL}, 217$ mmol) was added and stirring continued overnight. The reaction mixture was quenched following the work-up described above, to furnish the trialkylated ketone. The crude product was purified by Kugelrohr distillation $\left(150{ }^{\circ} \mathrm{C}, 180 \mathrm{~Pa}\right)$. The target product was obtained as a yellow oil in $79 \%$ yield. The product was contaminated with traces of and unknown impurity. ${ }^{1} \mathrm{H}$ NMR $\left(400 \mathrm{MHz}, \mathrm{CDCl}_{3}\right): \delta(\mathrm{ppm})=1.55$ (s, 9H), $7.34\left(\mathrm{dd}, 1 \mathrm{H},{ }^{3} J_{\mathrm{HH}}=4.9\right.$ and $\left.7.3 \mathrm{~Hz}\right), 7.86(\mathrm{~m}, 1 \mathrm{H}), 7.93(\mathrm{~m}$, $2 \mathrm{H}), 8.41\left(\mathrm{~d}, 1 \mathrm{H},{ }^{3} J_{H H}=8.2 \mathrm{~Hz}\right), 8.56\left(\mathrm{dd}, 1 \mathrm{H},{ }^{3} J_{\mathrm{HH}}=2.8\right.$ and $\left.6.4 \mathrm{~Hz}\right)$, $8.69\left(\mathrm{~d}, 1 \mathrm{H},{ }^{3} J_{\mathrm{HH}}=5.1 \mathrm{~Hz}\right) \cdot{ }^{13} \mathrm{C}\left\{{ }^{1} \mathrm{H}\right\}$ NMR (100 MHz, $\left.\mathrm{CDCl}_{3}\right)$ : $\delta(\mathrm{ppm})=27.83,40.29,121.17,123.31,123.83,124.10,137.16$, 137.92, 149.36, 149.17, 153.94, 154.41, $155.81\left(\mathrm{q},{ }^{2} J_{C F}=34.05\right.$ Hz).GC-MS (EI): 212 (17), 197 (9), 156 (100).

\section{$N$-(1-[2,2'-Bipyridin]-6-ylethylidene)-2,4,6-}

trimethylbenzenamine (5): The compound was prepared according to the published procedure with some modifications. ${ }^{19}$ A mixture of 2,4,6-trimethylaniline (1.45 mL, $10.1 \mathrm{mmol}), 2$ (2.00 g, $10.1 \mathrm{mmol})$, and formic acid (five drops) in $\mathrm{MeOH}(20.0 \mathrm{~mL}$ ) was heated to reflux temperature. After the mixture was allowed to cool to room temperature, and the solvent was removed under reduced pressure. The resulting oil was purified by Kugelrohr distillation $\left(240{ }^{\circ} \mathrm{C}, 140 \mathrm{~Pa}\right)$. The desired product was obtained as a yellow oil in $71 \%$ yield The product was contaminated with traces of an unknown impurity. ${ }^{1} \mathrm{H}$ NMR (400 MHz, $\left.\mathrm{CDCl}_{3}\right): \delta(\mathrm{ppm})=2.04(\mathrm{~s}, 6 \mathrm{H}), 2.31(\mathrm{~s}, 6 \mathrm{H}), 6.92(\mathrm{~s}, 2 \mathrm{H})$, $7.33(\mathrm{~m}, 1 \mathrm{H}), 7.84(\mathrm{~m}, 1 \mathrm{H}), 7.94\left(\mathrm{t}, 1 \mathrm{H},{ }^{3} J_{\mathrm{HH}}=7.8 \mathrm{~Hz}\right), 8.42(\mathrm{~d}, 1 \mathrm{H}$, $\left.{ }^{3} J_{H H}=7.8 \mathrm{~Hz}\right), 8.55\left(\mathrm{t}, 2 \mathrm{H},{ }^{3} J_{H H}=8.2 \mathrm{~Hz}\right), 8.71(\mathrm{~m}, 1 \mathrm{H}) .{ }^{13} \mathrm{C}\left\{{ }^{1} \mathrm{H}\right\}$ NMR (100.4 MHz, $\left.\mathrm{CDCl}_{3}\right): \delta(\mathrm{ppm})=16.58,17.98,20.84,121.16$, 121.26 , 122.02, 123.88, 125.38, 128.66, 132.25, 136.96, 137.45, 146.42, 149.27, 154.94, 155.87, 156.15, 167.61. GC-MS (EI): 315 (33), 300 (100).

$N$-(2,2-Dimethyl-[2,2'-bipyridin]-6-ylpropylidene)-2,4,6trimethylbenzenamine (6): The compound was prepared according to the published procedure with some modifications. ${ }^{20} \mathrm{~A}$ mixture of 2,4,6-trimethylaniline (0.89 mL, $6.24 \mathrm{mmol}), 4$ (1.00 g, $4.16 \mathrm{mmol})$, and $p$-toluenesulfonic acid monohydrate $(41.0 \mathrm{mg}, 0.21 \mathrm{mmol})$ in toluene (20.0 mL) was heated to reflux temperature (Dean-Stark trap). Afterthe mixture was allowed to cool to room temperature, and the solvent was removed under reduced pressure. The resulting oil was purified by Kugelrohr distillation $\left(240^{\circ} \mathrm{C}, 170 \mathrm{~Pa}\right)$. The desired product was obtained as a yellow powder in $43 \%$ yield. The product was contaminated with traces of an unknown impurity. ${ }^{1} \mathrm{H}$ NMR (400 $\left.\mathrm{MHz}, \mathrm{CDCl}_{3}\right): \delta(\mathrm{ppm})=1.42(\mathrm{~s}, 9 \mathrm{H}), 2.06(\mathrm{~s}, 6 \mathrm{H}), 2.08(\mathrm{~s}, 3 \mathrm{H}), 6.56$ (s, $2 \mathrm{H}), 6.76\left(\mathrm{~d}, 1 \mathrm{H},{ }^{3} J_{\mathrm{HH}}=7.4 \mathrm{~Hz}\right), 7.30(\mathrm{~m}, 1 \mathrm{H}), 7.52\left(\mathrm{t}, 1 \mathrm{H},{ }^{3} J_{\mathrm{HH}}=\right.$ $8.1 \mathrm{~Hz}), 7.82(\mathrm{~m}, 1 \mathrm{H}), 8.21\left(\mathrm{~d}, 1 \mathrm{H},{ }^{3} J_{H H}=7.9 \mathrm{~Hz}\right), 8.40\left(\mathrm{~d}, 1 \mathrm{H},{ }^{3} J_{H H}=\right.$ $7.9 \mathrm{~Hz}), 8.64(\mathrm{~m}, 1 \mathrm{H}) \cdot{ }^{13} \mathrm{C}\left\{{ }^{1} \mathrm{H}\right\}$ NMR $\left(100 \mathrm{MHz}, \mathrm{CDCl}_{3}\right): \delta(\mathrm{ppm})=$ 18.39, 20.72, 29.13, 40.52, 119.69, 121.17, 121.55, 123.89, 125.48, 128.26, 131.60, 136.30, 137.10, 149.18, 155.93, 156.09 (Two signals of aromatic carbons were not assignalbe due to coincident signals). GC-MS (EI): 300 (100).

$N$-(2,2,2-Trifluoro-[2,2'-bipyridin]-6-ylethylidene)-2,4,6trimethylbenzenamine (7): The compound was prepared according to the published procedure with some modifications. ${ }^{21} \mathrm{~A}$ mixture of 2,4,6-trimethylaniline ( $0.43 \mathrm{~mL}, 3.03 \mathrm{mmol}), 3$ (0.64 g, $2.53 \mathrm{mmol})$, and $p$-toluenesulfonic acid monohydrate $(14.6 \mathrm{mg}, 0.08 \mathrm{mmol})$ in toluene $(6.4 \mathrm{~mL})$ was heated to reflux temperature (Dean-Stark trap). After the mixture was allowed to cool to room temperature, and the solvent was removed under reduced pressure. The resulting oil was purified by Kugelrohr distillation $\left(200^{\circ} \mathrm{C}, 200 \mathrm{~Pa}\right)$. The desired product was obtained as a yellow powder in $79 \%$ yield. ${ }^{1} \mathrm{H}$ NMR (400 $\left.\mathrm{MHz}, \mathrm{CDCl}_{3}\right): \delta(\mathrm{ppm})=1.98(\mathrm{~s}, 6 \mathrm{H}), 2.21(\mathrm{~s}, 3 \mathrm{H}), 6.76(\mathrm{~s}, 2 \mathrm{H}), 7.12$ (d, $\left.1 \mathrm{H},{ }^{3} J_{H H}=7.6 \mathrm{~Hz}\right), 7.31(\mathrm{~m}, 1 \mathrm{H}), 7.74(\mathrm{~m}, 2 \mathrm{H}), 8.07\left(\mathrm{~d}, 1 \mathrm{H},{ }^{3} J_{H H}\right.$ $=8.1 \mathrm{~Hz}), 8.40\left(\mathrm{~d}, 1 \mathrm{H},{ }^{3} J_{\mathrm{HH}}=8.0 \mathrm{~Hz}\right), 8.63(\mathrm{br}, 1 \mathrm{H}) .{ }^{13} \mathrm{C}\left\{{ }^{1} \mathrm{H}\right\} \mathrm{NMR}$ $\left(100 \mathrm{MHz}, \mathrm{CDCl}_{3}\right): \delta(\mathrm{ppm})=17.91,20.82,121.28,121.77,122.20$, $123.10,124.32$, 124.48, 128.84, 133.61, 137.07, 137.49, 143.48, 
$147.92,149.14,155.18,156.17$ (One signal was not assignable due to coincident signal). Anal. Calcd. for $\mathrm{C}_{21} \mathrm{H}_{18} \mathrm{~F}_{3} \mathrm{~N}_{3}$ : C, 68.28; $\mathrm{H}, 4.91 ; \mathrm{N}$, 11.38. Found: C, 68.16; H, 5.00; N, 11.42. GC-MS (EI): 349 (37), 329 (18), 310 (16), 300 (100).

\section{$N$-(1-[2,2'-Bipyridin]-6-ylethylidene)-2,6-}

diisopropylbenzenamine (8): The compound was prepared according to the published procedure with some modifications. ${ }^{19}$ A mixture of 2,6-diisopropylaniline (2.11 mL, $10.1 \mathrm{mmol}$ ), 2 (2.00 g, 10.1 $\mathrm{mmol}$ ), and formic acid (five drops) in $\mathrm{MeOH}(20.0 \mathrm{~mL})$ was heated to reflux temperature. After the mixture was allowed to cool to room temperature, and the yellow solid was collected by filtration and washed with $\mathrm{MeOH}(10.0 \mathrm{~mL} \times 2)$. The target product was obtained as a yellow powder in $88 \%$ yield. ${ }^{1} \mathrm{H}$ NMR $\left(400 \mathrm{MHz}, \mathrm{CDCl}_{3}\right)$ : $\delta(\mathrm{ppm})=1.16\left(\mathrm{~d}, 12 \mathrm{H},{ }^{3} J_{\mathrm{HH}}=6.8 \mathrm{~Hz}\right), 2.33(\mathrm{~s}, 3 \mathrm{H}), 2.79(\mathrm{sept}, 2 \mathrm{H}$, $\left.{ }^{3} J_{H H}=6.6 \mathrm{~Hz}\right), 7.11(\mathrm{~m}, 1 \mathrm{H}), 7.18(\mathrm{~m}, 2 \mathrm{H}), 7.34(\mathrm{~m}, 1 \mathrm{H}), 7.85(\mathrm{~m}$, $1 \mathrm{H}), 7.95\left(\mathrm{t}, 1 \mathrm{H},{ }^{3} J_{\mathrm{HH}}=7.9 \mathrm{~Hz}\right), 8.40\left(\mathrm{bd}, 1 \mathrm{H},{ }^{3} \mathrm{~J}_{\mathrm{HH}}=7.3 \mathrm{~Hz}\right), 8.55(\mathrm{bt}$ $\left.2 \mathrm{H},{ }^{3} J_{\mathrm{HH}}=7.9 \mathrm{~Hz}\right), 8.71\left(\mathrm{bd}, 1 \mathrm{H},{ }^{3} J_{\mathrm{HH}}=4.4 \mathrm{~Hz}\right) .{ }^{13} \mathrm{C}\left\{{ }^{1} \mathrm{H}\right\} \mathrm{NMR}$ $\left(100.4 \mathrm{MHz}, \mathrm{CDCl}_{3}\right): \delta(\mathrm{ppm})=17.67,23.07,23.36,28.42,121.22$, $121.32,122.07,123.67,123.94,135.97,137.02,137.54,146.69$, 149.33, 155.04, 155.80, 156.21, 167.19. Anal. Calcd. for $\mathrm{C}_{24} \mathrm{H}_{27} \mathrm{~N}_{3}$ : C, 80.63; H, 7.61; N, 11.75. Found: C, 81.02; H, 7.70; N, 11.71. GC-MS (EI): 357 (20), 342 (67), 300 (19), 202 (72), 183 (27), 170 (22), 157 (100).

$N$-(2,2,2-Trifluoro-[2,2'-bipyridin]-6-ylethylidene)-2,6-

diisopropylbenzenamine (9): The compound was prepared according to the published procedure with some modifications. ${ }^{21} \mathrm{~A}$ mixture of 2,6-diisopropylaniline (0.85 mL, $4.03 \mathrm{mmol}), 3$ (1.02 g, 4.03 $\mathrm{mmol})$, and $p$-toluenesulfonic acid monohydrate $(23.3 \mathrm{mg}, 0.12$ $\mathrm{mmol})$ in toluene $(10.2 \mathrm{~mL})$ was heated to reflux temperature (DeanStark trap). After the mixture was allowed to cool to room temperature, and the solvent was removed under reduced pressure. The resulting oil was purified by Kugelrohr distillation $\left(210{ }^{\circ} \mathrm{C}, 140 \mathrm{~Pa}\right)$. The desired product was obtained as a yellow oil in $55 \%$ yield. The product was contaminated with traces of an unknown impurity. ${ }^{1} \mathrm{H}$ NMR $\left(400 \mathrm{MHz}, \mathrm{CDCl}_{3}\right): \delta(\mathrm{ppm})=1.18\left(\mathrm{~d}, 12 \mathrm{H},{ }^{3} J_{\mathrm{HH}}=6.8 \mathrm{~Hz}\right), 2.78$ (sept, $\left.2 \mathrm{H},{ }^{3} J_{\mathrm{HH}}=6.4 \mathrm{~Hz}\right), 7.10(\mathrm{~m}, 3 \mathrm{H}), 7.17\left(\mathrm{~d}, 1 \mathrm{H},{ }^{3} J_{\mathrm{HH}}=6.7 \mathrm{~Hz}\right), 7.29(\mathrm{t}$, $\left.1 \mathrm{H},{ }^{3} J_{H H}=6.2 \mathrm{~Hz}\right), 7.72\left(\mathrm{t}, 2 \mathrm{H},{ }^{3} J_{H H}=6.7 \mathrm{~Hz}\right), 7.87\left(\mathrm{~d}, 1 \mathrm{H},{ }^{3} J_{\mathrm{HH}}=7.1\right.$ $\mathrm{Hz}), 8.40\left(\mathrm{~d}, 1 \mathrm{H},{ }^{3} J_{\mathrm{HH}}=7.6 \mathrm{~Hz}\right), 8.62(\mathrm{br}, 1 \mathrm{H}) .{ }^{13} \mathrm{C}\left\{{ }^{1} \mathrm{H}\right\}$ NMR $(100$ $\left.\mathrm{MHz}, \mathrm{CDCl}_{3}\right): \delta(\mathrm{ppm})=22.36,28.45,121.92,122.31,123.43$, $123.78,124.33,124.77,134.57,137.00,137.46,143.73,147.06$, 149.09, $153.45\left(\mathrm{q},{ }^{2} J_{C F}=33.01 \mathrm{~Hz}\right), 155.08,156.06$ (One signal was not assignable due to coincident signal). GC-MS (EI): 411 (11), 368 (10), 342 (100).

$N$-(1-[2,2'-Bipyridin]-6-ylethylidene)-2,4,6trimethylbenzenamine iron(II) bromide $\left(\left({ }^{\mathrm{H}} \mathrm{BPI}^{\mathrm{Mes}, \mathrm{Me}}\right) \mathrm{FeBr}_{2}\right)$ : $\mathrm{FeBr}_{2}$ (anhydrous) (1.98 g, $6.26 \mathrm{mmol}$ ) was added to a solution of 5 $(1.38 \mathrm{~g}, 6.26 \mathrm{mmol})$ in THF $(100 \mathrm{~mL})$ at room temperature with vigorous stirring. The precipitate formed during the reaction was collected by filtration, washed three times with THF $(10 \mathrm{~mL})$, and dried in vacuo. ( $\left.{ }^{\mathrm{H}} \mathrm{BPI}^{\mathrm{Mes}, \mathrm{Me}}\right) \mathrm{FeBr}_{2}$ was obtained as a brownish-purple powder in $99 \%$ yield. Anal. Calcd. for $\mathrm{C}_{42} \mathrm{H}_{44} \mathrm{Br}_{4} \mathrm{Fe}_{2} \mathrm{~N}_{6} \mathrm{O}\left(2 \mathrm{M}+\mathrm{H}_{2} \mathrm{O}\right)$ : C, 46.70; H, 4.11; N, 7.78. Found: C, 47.12; H, 4.22; N, 7.37. HRMS (FAB): Calcd. for $\mathrm{C}_{21} \mathrm{H}_{21} \mathrm{FeN}_{3}$ [M-2Br] ${ }^{+}$: 371.1085, Found: 371.1084.

\section{$N$-(2,2-Dimethyl-[2,2'-bipyridin]-6-ylpropylidene)-2,4,6-}

trimethylbenzenamine iron(II) bromide $\left(\left({ }^{\mathrm{H}} \mathrm{BPI}^{\mathrm{Mes}, \mathrm{BBu}}\right) \mathrm{FeBr}_{2}\right)$ : This complex was prepared as a bluish-purple powder in 56\% yield following the procedure above for $\left({ }^{\mathrm{H}} \mathrm{BPI}^{\mathrm{Mes}, \mathrm{Me}}\right) \mathrm{FeBr}_{2}$. Anal. Calcd. for $\mathrm{C}_{240} \mathrm{H}_{270} \mathrm{Br}_{22} \mathrm{Fe}_{11} \mathrm{~N}_{30}\left(10 \mathrm{M}+\mathrm{FeBr}_{2}\right): \mathrm{C}, 48.47 ; \mathrm{H}, 4.58 ; \mathrm{N}, 7.07$. Found: C, 48.46; H, 4.73; N, 7.10. HRMS (FAB): Calcd. for $\mathrm{C}_{24} \mathrm{H}_{27} \mathrm{FeN}_{3}$ [M$2 \mathrm{Br}]^{+}$: 413.1554, Found: 413.1550.

$N$-(2,2,2-Trifluoro-[2,2'-bipyridin]-6-ylethylidene)-2,4,6trimethylbenzenamine iron(II) bromide $\left(\left({ }^{\mathrm{H}} \mathrm{BPI}^{\mathrm{Mes}, \mathrm{CF} 3}\right) \mathrm{FeBr}_{2}\right)$ : This complex was prepared as a brown powder in $88 \%$ yield following the procedure above for $\left({ }^{\mathrm{H}} \mathrm{BPI}^{\mathrm{Mes}, \mathrm{Me}}\right) \mathrm{FeBr}_{2}$. Anal. Calcd. for $\mathrm{C}_{48} \mathrm{H}_{50} \mathrm{Br}_{4} \mathrm{~F}_{6} \mathrm{Fe}_{2} \mathrm{~N}_{6}$ (2M+hexane): $\mathrm{C}, 45.89 ; \mathrm{H}, 4.01 ; \mathrm{N}, 6.69$. Found: $\mathrm{C}$, 45.81; $\mathrm{H}, 4.00$; N, 6.51. HRMS (FAB): Calcd. for $\mathrm{C}_{21} \mathrm{H}_{18} \mathrm{~F}_{3} \mathrm{FeN}_{3}[\mathrm{M}-$ $2 \mathrm{Br}]^{+}:$425.0802, Found: 425.0801.

$N$-(1-[2,2'-Bipyridin]-6-ylethylidene)-2,6diisopropylbenzenamine iron(II) bromide $\left(\left({ }^{\mathrm{H}} \mathrm{BPI}^{\mathrm{Dipp}, \mathrm{Me}}\right) \mathrm{FeBr}_{2}\right)$ : This complex was prepared as a red-purple powder in $83 \%$ yield fol- lowing the procedure above for $\left({ }^{\mathrm{H}} \mathrm{BPI}^{\mathrm{Mes}, \mathrm{Me}}\right) \mathrm{FeBr}_{2}$. Anal. Calcd. for $\mathrm{C}_{24} \mathrm{H}_{27} \mathrm{Br}_{2} \mathrm{FeN}_{3}$ : C, 50.29; H, 4.75; N, 7.33. Found: C, 49.99; H, 4.82; N, 7.20. HRMS (FAB): Calcd. for $\mathrm{C}_{24} \mathrm{H}_{27} \mathrm{FeN}_{3}[\mathrm{M}-2 \mathrm{Br}]^{+}$: 413.1554, Found: 413.1562 .

$N$-(2,2,2-Trifluoro-[2,2'-bipyridin]-6-ylethylidene)-2,6diisopropylbenzenamine iron(II) bromide $\left(\left({ }^{\mathrm{H}} \mathrm{BPI}^{\mathrm{Dipp}, \mathrm{CF} 3}\right) \mathrm{FeBr}_{2}\right)$ : This complex was prepared as an emerald green powder in $56 \%$ yield following the procedure above for $\left({ }^{\mathrm{H}} \mathrm{BPI}^{\mathrm{Mes}, \mathrm{Me}}\right) \mathrm{FeBr}_{2}$. Anal. Calcd. for $\mathrm{C}_{24} \mathrm{H}_{24} \mathrm{Br}_{2} \mathrm{~F}_{3} \mathrm{FeN} \mathrm{N}_{3}$ : C, 45.97; H, 3.96; N, 6.70. Found: C, 45.91; H, 3.97; N, 6.72. HRMS (FAB): Calcd. for $\mathrm{C}_{24} \mathrm{H}_{24} \mathrm{~F}_{3} \mathrm{FeN}_{3}$ [M-2Br] ${ }^{+}$: 467.1272, Found: 467.1255.

Typical Procedure for the Catalytic Hydrosilylation of Olefins with Silanes: $\left({ }^{\mathrm{H}} \mathrm{BPI}^{\mathrm{Mes}, \mathrm{H}}\right) \mathrm{FeBr}_{2}(3.0 \mathrm{mg}, 0.0058 \mathrm{mmol})$ was placed in a Schlenk tube in air at room temperature. Next, the air in the Schlenk tube was replaced with nitrogen. 1-Octene $(18 \mathrm{~mL}, 120 \mathrm{mmol})$ and phenylsilane $(7.2 \mathrm{~mL}, 58 \mathrm{mmol})$ were added to the Schlenk tube. Sodium triethylborohydride ( $1.0 \mathrm{M}$ in toluene, $120 \mu \mathrm{L}, 0.12 \mathrm{mmol})$ was then added to the suspension at room temperature, leading to the formation of a homogeneous dark brown solution within several minutes. The evolution of heat from the reaction suggested of an exothermic reaction. The solution was stirred without any temperature control for $24 \mathrm{~h}$ and eventually exposed to air. The reaction mixture was subjected to HPLC analysis to determine the TON.

DFT Calculations: All calculations were performed using the Gaussian 09 program. ${ }^{13}$ The geometry of $\left({ }^{\mathrm{H}} \mathrm{BPI}^{\mathrm{Ar}, \mathrm{R}}\right) \mathrm{Fe}$ was optimized by the DFT method with the B3LYP functional. ${ }^{14-16}$ For the Fe atom, SDD basis set was used with the corresponding ECPs. ${ }^{17}$ Usual 6$31 \mathrm{G}(\mathrm{d}, \mathrm{p})$ basis sets were used for other atoms. ${ }^{16}$ Frequency calculations, at the same level, were performed on optimized structures to ensure that minima exhibit only a positive frequency. The molecular structures were drawn using the GaussView version 4.1.2. program. $\mathrm{NBO}$ analysis ${ }^{18}$ was performed to investigate the $\mathrm{Fe}-\mathrm{N}$ and/or Fe-C interactions in $\left({ }^{\mathrm{H}} \mathrm{BPI}^{\mathrm{Ar}, \mathrm{R}}\right) \mathrm{Fe}$.

\section{AUTHOR INFORMATION}

\section{Corresponding Author}

*E-mail: nakazawa@sci.osaka-cu.ac.jp

Notes

Any additional relevant notes should be placed here.

\section{ACKNOWLEDGMENT}

This work was supported by the "Development of Innovative Catalytic Processes for Organosilicon Functional Materials" project (PL: K. Sato) form the New Energy and Industrial Technology Development Organization (NEDO).

\section{REFERENCES}

(1) For example, see: (a) Cheng, C.; Hartwig, J. F. Chem. Rev. 2015, 115, 8946. (b) Rücker, C.; Kümmerer, K. Chem. Rev. 2015, 115, 466. (c) Bauer, I.; Knölker, H. Chem. Rev. 2015, 115, 3170. (d) Moitra, N.; Ichii, S.; Kamei, T.; Kanamori, K.; Zhu, Y.; Takeda, K.; Nakanishi, K.; Shimada, T. J. Am. Chem. Soc. 2014, 136, 11570. (e) Min, G. K.; Acil, D.; Andez, H.; Skrydstrup, T. Acc. Chem. Res. 2013, 46, 457. (f) Onoe, M.; Baba, K.; Kim, Y.; Kita, Y.; Tobisu, M.; Chatani, N. J. Am. Chem. Soc. 2012, 134, 19477. (g) Lu, P.; Lam, J. W. Y.; Liu, J.; Jim, C. K. W.; Yuan, W.; Chan, C. Y. K.; Xie, N.; Hu, Q.; Cheuk, K. K. L.; Tang, B. Z. Macromolecules 2011, 44, 5977. (h) Ishifune, M.; Sana, C.; Ando, M.; Tsuyama, Y. Polym. Int. 2011, 60, 1208. (i) Will, U.; Veljanovski, D.; Härter, P.; Rieger, B. Macromolecules 2010, 43, 934.

(2) For recent reports, see: (a) Smirnov, P.; Oestreich, M. Organometallics 2016, 35, 2433. (b) Meister, T. K.; Riener, K.; Gigler, P.; Stohrer, J.; Herrmann, W. A.; Kühn, F. E. ACS Catal. 2016, 6, 1274. (c) Galeandro-Diamant, T.; Zanota, M.-L.; Sayah, R.; Veyre, L.; Nikitine, C.; de Bellefon, C.; Marrot, S.; Meille, V.; Thieuleux, C. Chem. Commun. 2015, 16194. (d) Dierick, S.; Vercruysse, E.; Berthon-Gelloz, G.; Markó, I. E. Chem. Eur. J. 2015, 21, 17073. (e) 
Henderson, I. M.; Quintana, H. A.; Martinez, J. A.; Paxton, W. F. Chem. Mater. 2015, 27, 4808

(3) (a) Peng, D.; Zhang, Y.; Du, X.; Zhang, L.; Leng, X.; Walter, M. D.; Huang, Z. J. Am. Chem. Soc. 2013, 135, 19154. (b) Peoples, B. C.; Rojas, R. S. In Olefin Upgrading Catalysis by Nitrogen-Based Metal Complexes II; Giambastiani, G., Cámpora, J., Eds.; Springer: Berlin, 2011; pp 39-75. (c) Choi, J.; MacArthur, A. H. R.; Brookhart, M.; Goldman, A. S. Chem. Rev. 2011, 111, 1761.

(4) (a) Tondreau, A. M.; Atienza, C. C. H.; Weller, K. J.; Nye, S. A.; Lewis, K. M.; Delis, J. G. P.; Chirik, P. J. Science 2012, 335, 567. (b) Atienza, C. C. H.; Tondreau, A. M.; Weller, K. J.; Lewis, K. M.; Cruse, R. W.; Nye, S. A.; Boyer, J. L.; Delis, J. G. P.; Chirik, P. J. ACS Catal. 2012, 2, 2169. (c) Tondreau, A. M.; Atienza, C. C. H.; Darmon, J. M.; Milsmann, C.; Hoyt, H. M.; Weller, K. J.; Nye, S. A.; Lewis, K. M.; Boyer, J.; Delis, J. G. P.; Lobkovsky, E.; Chirik, P. J. Organometallics 2012, 31, 4886.

(5) Kamata, K.; Suzuki, A.; Nakai, Y.; Nakazawa, H. Organometallics 2012, 31, 3825.

(6) Chen, J.; Cheng, B.; Cao, M.; Lu, Z. Angew. Chem. Int. Ed. 2015, 54, 4661.

(7) Challinor A. J.; Calin, M.; Nichol, G. S.; Carter, N. B.; Thomas, S. P. Adv. Synth. Catal. 2016, 358, 2404.

(8) (a) Du, X.; Zhang, Y.; Peng, D.; Huang, Z. Angew. Chem. Int Ed. 2016, 55, 6671. (b) Peng, D.; Zhang, Y.; Du, X.; Zhang, L.; Leng, X.; Walter, M. D.; Huang, Z. J. Am. Chem. Soc. 2013, 135, 19154.

(9) Gilbert-Wilson, R.; Chu, W.-Y.; Rauchfuss, T. B. Inorg. Chem. 2015, 54, 5596.

(10) Hayasaka, K.; Kamata, K.; Nakazawa, H. Bull. Chem. Soc. Jpn. 2016, 89, 394

(11) Fe-catalyzed reactions: (a) Noda, D.; Tahara, A.; Sunada, Y.; Nagashima, H. J. Am. Chem. Soc. 2016, 138, 2480. (b) Challinor, A. J.; Calin, M.; Nichol, G. S.; Carter, N. B.; Thomas, S. P. Adv. Synth. Catal. 2016, 358, 2404. (c) Du, X.; Zhang, Y.; Peng, D.; Huang, Z. Angew. Chem. Int. Ed. 2016, 55, 6671. (d) Marciniec, B.; Kownacka, A.; Kownacki, I.; Hoffmann, M.; Taylor, R. J. Organomet. Chem. 2015, 791, 58. (e) Sunada, Y.; Noda, D.; Soejima, H.; Tsutsumi, H.; Nagashima, H. Organometallics 2015, 34, 2896. (f) Jia, X.; Huang, Z. Nat. Chem. 2015, 8, 157. (g) Chen, J.; Cao, M.; Cheng, B.; Lu, Z. Synlett 2015, 26, 2332. (h) Sunada, Y.; Tsutsumi, H.; Shigeta, K.; Yoshida, R.; Hashimoto, T.; Nagashima, H. Dalton Trans. 2013, 42, 16687. (i) Naumov, R. N.; Itazaki, M.; Kamitani, M.; Nakazawa, H. J. Am. Chem. Soc. 2012, 134, 804. (j) Belger, C.; Plietker, B. Chem. Commun. 2012, 48, 5419. (k) Enthaler, S.; Haberberger, M.; Irran, E. Chem. Asian J. 2011, 6, 1613.

(12) Co-catalyzed reactions: (a) Schuster, C. H.; Diao, T.; Pappas, I.; Chirik, P. J. ACS Catal. 2016, 6, 2632. (b) Ibrahim, A. D.;
Entsminger, S. W.; Zhu, L.; Fout, A. R. ACS Catal. 2016, 6, 3589. (c) Raya, B.; Biswas, S.; RajanBabu, T. V. ACS Catal. 2016, 6, 6318. (d) Wang, C.; Teo, W. J.; Ge, S. ACS Catal. 2017, 7, 855. (e) Chu, W.Y.; Gilbert-Wilson, R.; Rauchfuss, T. B.; van Gastel, M.; Neese, F. Organometallics 2016, 35, 2900. (f) Sun, J.; Deng, L. ACS Catal. 2016, 6, 290. (g) Chen, C.; Hecht, M. B.; Kavara, A.; Brennessel, W. W.; Mercado, B. Q.; Weix, D. J.; Holland, P. L. J. Am. Chem. Soc. 2015, 137, 13244. (h) Mo, Z.; Xiao, J.; Gao, Y.; Deng, L. J. Am. Chem. Soc. 2014, 136, 17414. (i) Atienza, C. C. H.; Diao, T.; Weller, K. J.; Nye, S. A.; Lewis, K. M.; Delis, J. G. P.; Boyer, J. L.; Roy, A. K.; Chirik, P. J. J. Am. Chem. Soc. 2014, 136, 12108.

(13) Gaussian 09, Revision A.01, Frisch, M. J.; Trucks, G. W.; Schlegel, H. B.; Scuseria, G. E.; Robb, M. A; Cheeseman, J. R.; Scalmani, G.; Barone, V.; Mennucci, B.; Petersson, G. A.; Nakatsuji, H.; Caricato, M.; Li, X.; Hratchian, H. P.; Izmaylov, A. F.; Bloino, J.; Zheng, G.; Sonnenberg, J. L.; Hada, M.; Ehara, M.; Toyota, K.; Fukuda, R.; Hasegawa, J.; Ishida, M.; Nakajima, T.; Honda, Y.; Kitao, O.; Nakai, H.; Vreven, T,; Montgomery, Jr., J. A.; Peralta, J. E.; Ogliaro, F.; Bearpark, M.; Heyd, J. J.; Brothers, E.; Kudin, K. N.; Staroverov, V. N.; Kobayashi, R.; Normand, J.; Raghavachari, K.; Rendell, A.; Burant, J. C.; Iyengar, S. S.; Tomasi, J.; Cossi, M.; Rega, N.; Millam, J. M.; Klene, M.; Knox, J. E.; Cross, J. B.; Bakken, V.; Adamo, C.; Jaramillo, J.; Gomperts, R.; Stratmann, R. E.; Yazyev, O.; Austin, A. J.; Cammi, R.; Pomelli, C.; Ochterski, J. W.; Martin, R. L.; Morokuma, K.; Zakrzewski, V. G.; Voth, G. A.; Salvador, P.; Dannenberg, J. J.; Dapprich, S.; Daniels, A. D.; Farkas, O.; Foresman, J. B.; Ortiz, J. V.; Cioslowski, J.; Fox, D. J. Gaussian, Inc., Wallingford CT, 2009.

(14) (a) Becke, A. D. J. Chem. Phys. 1993, 98, 5648. (b) Becke, A. D. Phys. Rev. 1988, A38, 3098.

(15) Vosko, S. H., Wilk, L.; Nusair, M. Can. J. Phys. 1980, 58, 1200

(16) (a) Miehlick, B.; Savin, A.; Stoll, H.; Preuss, H. Chem. Phys. Lett. 1989, 157, 200. (b) Lee, C.; Yang, W.; Parr, R. G. Phys. Rev. 1988, B37, 785.

(17) Dolg, M.; Stoll, H.; Preuss, H.; Pitzer, R. M. J. Phys. Chem. 1993, 97, 5852 .

(18) Reed, A. E.; Weinhold, F. J. Chem. Phys. 1985, 83, 1736.

(19) Champouret, Y. D. M.; Maréchal, J.-D.; Chaggar, R. K.; Fawcett, J.; Singh, K.; Maseras, F.; Solan, G. A. New. J. Chem. 2007, 31, 75.

(20) Díaz-Valenzuela, M. B.; Phillips, S. D.; France, M. B.; Gunn, M. E.; Clarke, M. L. Chem. Eur. J. 2009, 15, 1227.

(21) Dai, X.; Cahard, D. Adv. Synth. Catal. 2014, 356, 1317.

Authors are required to submit a graphic entry for the Table of Contents (TOC) that, in conjunction with the manuscript title, should give the reader a representative idea of one of the following: A key structure, reaction, equation, concept, or theorem, etc., that is discussed in the manuscript. Consult the journal's Instructions for Authors for TOC graphic specifications.

Insert Table of Contents artwork here

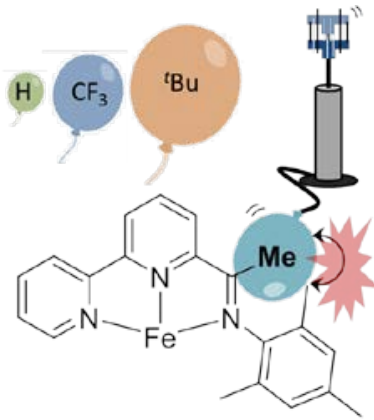


NNN-pincer iron complexes bearing ketamine-type iminobipyridine ligands were effective catalysts for hydrosilylation of olefins using primary, secondary, and tertiary silanes. The appropriate combination of the imino carbon and imino nitrogen substituents led to the complexes with quite high catalytic activity: the turnover number achieved was up to 42000 . 